
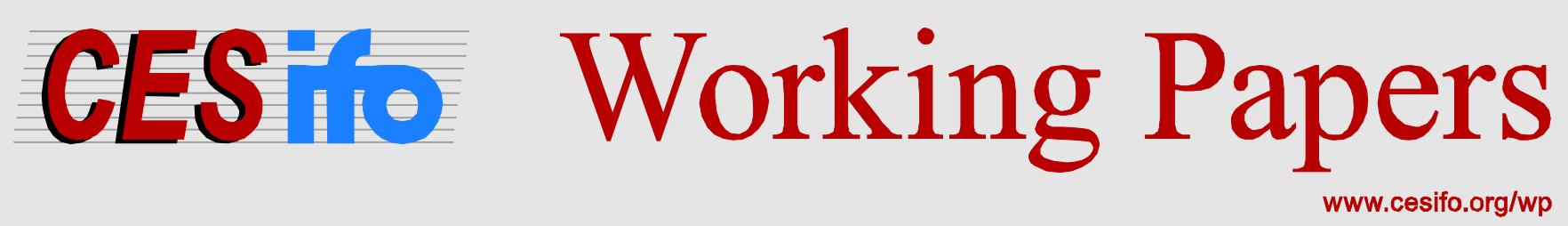

\title{
Boosting and Regional Economic Forecasting: The Case of Germany
}

\author{
Robert Lehmann \\ Klaus Wohlrabe
}

\author{
CESIFO WORKING PAPER NO. 6157 \\ CATEgORY 6: Fiscal POLICY, MACROECONOMICS AND GROWTH \\ OCTOBER 2016
}
An electronic version of the paper may be downloaded
- from the SSRN website:
- from the RePEc website:
- from the CESifo website: www.SSRN.com
www.RePEc.org
www.CESifo-group.org/wp




\title{
Boosting and Regional Economic Forecasting: The Case of Germany
}

\begin{abstract}
This paper applies component-wise boosting to the topic of regional economic forecasting. Component-wise boosting is a pre-selection algorithm of indicators for forecasting. By using unique quarterly real gross domestic product data for two German states (the Free State of Saxony and Baden-Wuerttemberg) and Eastern Germany for the period from 1997 to 2013, in combination with a large data set of monthly indicators, we show that boosting is generally doing a very good job in regional economic forecasting. We additionally take a closer look into the algorithm and ask which indicators get selected. All in all, boosting outperforms our benchmark model for all the three regions considered. We also find that indicators that mirror the region-specific economy get frequently selected by the algorithm.
\end{abstract}

JEL-Codes: C530, E170, E370, R110.

Keywords: boosting, regional economic forecasting, gross domestic product.

Robert Lehmann*

Ifo Institute - Leibniz Institute for

Economic Research

at the University of Munich

Poschingerstrasse 5

Germany-81679 Munich

lehmann@ifo.de
Klaus Wohlrabe

Ifo Institute - Leibniz Institute for

Economic Research

at the University of Munich

Poschingerstrasse 5

Germany-81679 Munich

wohlrabe@ifo.de

*corresponding author

This version: October 19, 2016 


\section{Introduction}

The need of region-specific economic forecasts by policy-makers from sub-national entities has increased over the last years. We can identify two major reasons why regional economic forecasts recently become more important. First, these forecasts are the basis for the regional decision-making process, for example, for fiscal policy planning. And second, regional gross domestic product (GDP) often markedly develops in a different way compared to countries as a whole because of specific regional economic structures. A regional economic forecast therefore serves as an additional information source for the policy-maker and as an early warning system.

Not only policy-makers are more interested in region-specific forecasts, but the topic of regional economic forecasting is also increasingly becoming part of literature in this field in recent years. A recent survey on regional economic forecasting is provided by Lehmann and Wohlrabe (2014b). This survey discusses state-of-the-art methodology in regional economic forecasting and names possible future research activities in this field. One of such activities could be examining the forecasting performance of boosting algorithms for regional economic development. In this paper, we fill this gap in the existing literature by looking at the forecasting performance for three regional entities in Germany. It turns out that boosting outperforms the benchmark model, especially in the case of one- and two-quarter-ahead predictions. Additionally, the algorithm mostly selects those variables that mirror the regionspecific economic structure.

Boosting is, generally speaking, a multivariate large data set method that is able to preselect the most relevant predictors for a specific target variable, with respect to all other potential indicators, by simultaneously shrinking the influence of less relevant predictors towards zero (see, among others, Bai and $\mathrm{Ng}$, 2009). Thus, boosting ends up in an either linear or nonlinear function that can easily be handled by standard estimation techniques such as ordinary least squares (OLS) and macroeconomic forecasting issues. Compared to other multivariate large data set methods such as least angle regression (LARS) and least absolute shrinkage selection operator (LASSO), boosting is a 'statistical learning procedure' that works in a similar fashion but is not exactly the same (Efron et al., 2004). Simply speaking, all three models iteratively fit a linear model by regressing the set of potential predictors to the residuals of the former regression step. In each step, the regression coefficients become 'penalized' in order to shrink the influence of less informative indicators towards zero. Closely related to this penalization are the methods elastic net (EN) and non-negative garotte (NNG) which put modified restrictions or criteria on the coefficient estimates. Another way to reduce the number of potential predictors before forecasting economic time series is the classical diffusion index methodology or factor analysis. However, factor models differ in a very essential way from these large data set methods: the indicator reduction is independent from the target series to be forecasted. From the large 
set of indicators, the operator extracts a small number of common factors that can be used to forecast each macroeconomic time series (or even any other series of interest). However, this factor extraction can be suboptimal since a set of indicators can have a noisy character or less power in forecasting a specific time series (Bai and $\mathrm{Ng}, 2009$ ). This noisiness may introduce biases to the forecast. Additionally, it is completely arbitrary how many factors are extracted from the data, therefore test for the optimal number of factors are needed. The last way of dealing with a large set of information are forecast combinations. In contrast to the methods mentioned before where the indicators are filtered first and used for forecasting after, forecast combinations or pooling takes place after the forecasts are generated. Pooling is therefore an aggregation of a large number of different forecasts (for example, from individual indicators) based on a specific aggregation rule (for example, a simple average). Thus, forecast combination is a completely different approach and by no means a pre-selection of indicators.

The existing literature finds that boosting is a well performing alternative. Bai and $\mathrm{Ng}$ (2009) focus on the forecasting performance of boosting for four US macroeconomic variables. They find an improvement of boosting over factor-augmented forecasts and simple autoregressive models. Especially for the US industrial production, Buchen and Wohlrabe (2011) certify boosting to be a tough forecasting competitor compared to forecast combinations or factor models. Robinzonov et al. (2012) found an improvement of boosting over autoregressive models for German industrial production. A recent study is the one by Zeng (2016). She asks whether boosting is a able to filter from a pool of disaggregated variables the most relevant predictors to forecast aggregates. For six euro area macroeconomic variables boosting is doing a very good job to forecast these aggregates. Next to standard macroeconomic variables, boosting has also been used for financial variables. Andrada-Félix and Fernández-Rodríguez (2008) evaluate the performance of boosting in order to forecast the NYSE Composite Indicator. They found a forecast improvement with boosting compared to simple moving average trading rules. The articles by Pierdzioch et al. $(2016,2015)$ focus on gold and silver prices. In both articles boosting is found to have predictive power. The last two papers that are relevant for our study are those by Buchen and Wohlrabe (2014) and Lehmann and Wohlrabe (2016). Whereas the first study sets up a 'simulation' for US, European and German macroeconomic variables in order to find how parameters of the algorithm should optimally be chosen, the second study takes a closer look into the boosting algorithm and asks which indicators are frequently selected. All these studies focus on countries. To the best of our knowledge, studies for regional entities are missing.

This paper is related to Lehmann and Wohlrabe (2016) as well as Kim and Swanson (2014) and has two major contributions. First, we generally ask whether boosting produces lower forecast errors for regional gross domestic product compared to a simple benchmark model. And second, we take a closer look into the boosting procedure. To be more precise, we ask whether there are superior indicators for regional economic forecasting that get selected 
into the model by the algorithm. The main focus here lies on the investigation of regional entities. So our paper is by no means a study that compares large data set methods with each other for different regions. It rather focuses on the specific selection of indicators for forecasting regional economic development. We think that it is more fruitful to ask where the information for regional economic forecasting come from, instead of comparing different methodologies with each other. Up to date, the sparse regional economic forecasting literature only applies pooling and factor models as large data set methods (see Lehmann and Wohlrabe, 2015, 2014a). Boosting seems therefore be a promising alternative, so that this study rather complements the existing ones. But why should we use boosting for regional economic forecasting? We see one striking argument: one additional dimension that provides potential indicators. Whereas most of the studies for countries use national and international data, we can add the regional dimension as well. We think that regional economic development is influenced by international economic shocks, nationwide economic linkages and region-specific developments. Thus, the set of potential predictors is even larger than for national studies. Additionally, in comparison to factor models, boosting is an alternative to select indicators. This makes boosting especially interesting for practitioner, since regional economic forecasters want to know on which indicators they should focus on. But we have to state that boosting is a pure time-series-based technique, so that we forecast each regional entity separately. Spatial connections or interdependency are neglected in our case.

The paper is organized as follows: Section 2 introduces the regional data sets, followed by the presentation of the boosting algorithm and forecasting approach. In Section 3 we discuss the results in detail. The final section offers some conclusions.

\section{Regional Economic Forecasting and Boosting}

\subsection{Data}

National accounts data for regional entities such as counties or districts are generally only available on an annual basis. Since large data set methods such as boosting only work with a sufficient number of observations, annual information is not suitable for our purposes. However, as in Lehmann and Wohlrabe (2015), we can rely on quarterly gross domestic product (GDP) data for two German states (the Free State of Saxony and Baden-Wuerttemberg) as well as Eastern Germany. ${ }^{1}$ Thus, we can compare the performance of boosting for three different regional entities.

\footnotetext{
${ }^{1}$ Eastern Germany comprises the five German states Brandenburg, Mecklenburg-Western Pomerania, Saxony-Anhalt, the Free State of Saxony and the Free State of Thuringia. The German states equal the NUTS-1-classification of Europe.
} 


\subsubsection{The Free State of Saxony}

Saxony is part of the Eastern German states that joined Germany after its reunification in 1989 and lies in the south-east of Germany. Compared to all German states, the Free State of Saxony had the eighth largest share of total nominal German GDP in $2014(\approx 4 \%)$. If we focus on Eastern Germany (without Berlin) instead, Saxony has the highest nominal GDP compared to all of the other Eastern German states. Additionally, the Free State of Saxony is the Eastern German state with the highest industrial share and the largest export quota.

The quarterly data for Saxony are provided by the German Ifo Institute (Nierhaus, 2007). ${ }^{2}$ The calculations are based on the temporal disaggregation procedure by Chow and Lin (1971) that applies a stable relationship between the target series and a suitable indicator. Thus, a variable with low frequency (here: annual GDP figures) is transformed via specific indicators into a series with higher frequency (quarterly figures as in our case). Official regional statistics such as turnover in manufacturing serve as suitable indicators. This paper uses real quarterly GDP data for Saxony ranging from 1997Q1 to 2013Q4. These figures are calculated according to the latest available classification of national accounts. The series is seasonally adjusted and we apply a year-on-year growth rate transformation to reach stationarity.

In the Saxon case, we can rely on a data set that contains 234 monthly indicators. This data set is predominantly the same as in Henzel et al. (2015). In order to systematize the indicators, we group them into six categories: macroeconomic (72), prices (11), surveys (56), international (26) and regional (69). The indicators from the first three categories are measured at the national level (here: Germany). Since Saxony can be considered as a small open economy, we expect international indicators to deliver useful information to forecast Saxon GDP. In order to capture region-specific developments, we add indicators that are measured at the regional level (here: Saxony). Of course, the indicators used for disaggregation do not enter the forecasting experiment described later on. All indicators are also seasonally adjusted. Since the potential predictors are measured on a monthly basis, we either apply a three-month-average or the three-month-sum to obtain quarterly data. Whenever indicators are not stationary in levels, we either calculate year-on-year growth rates or first differences to the quarter of the previous year.

\subsubsection{Baden-Wuerttemberg}

Baden-Wuerttemberg was in terms of GDP per capita the third richest state (excluding the city states Bremen and Hamburg) in Germany in 2014. It lies in the south-west of Germany and hosts large firms such as the Bosch-Group or Mercedes. In 2014, Baden-Wuerttemberg contributed with approximately $15 \%$ to total German GDP, which was the third highest share. Baden-Wuerttemberg has also one of the most open economies in Germany; more

${ }^{2}$ The latest data for Saxony are available upon request from dresden@ifo.de 
than $50 \%$ of all industrial turnover are gained in foreign countries. Thus, the structural differences to the Saxon economy makes our analysis even more interesting, since we compare the forecasting performance of boosting for two very different regional entities.

The quarterly GDP data for Baden-Wuerttemberg are also calculated with the method of Chow and Lin (1971) and provided by the Statistical Office of Baden-Wuerttemberg (Vullhorst, 2008). ${ }^{3}$ As in the Saxon case, the real quarterly GDP data for Baden-Wuerttemberg are available for the period 1997Q1 to 2013Q4, seasonal adjusted and transformed in yearon-year growth rates.

For Baden-Wuerttemberg we use a data set that contains 201 monthly indicators. The distribution between the categories is the same, with one exception: for Baden-Wuerttemberg we can only rely on 36 regional indicators. As before, we only consider indicators that are not used for temporal disaggregation. Again, all monthly indicators are seasonally adjusted and transformed to quarterly as well as stationary information.

\subsubsection{Eastern Germany}

The five Eastern German states (excluding Berlin) are structural completely different from their Western German counterparts. Eastern Germany is characterized by higher unemployment rates, a lower GDP per capita, tougher demographic developments and missing headquarters (only to name a few problems; see Ragnitz, 2005). We thus suggest to find differences in the forecasting performance of boosting compared to the before mentioned states.

Quarterly GDP data for Eastern Germany are provided by the Halle Institute for Economic Research (abbreviated in German as IWH) and are regularly published under the name 'Barometer for Economic Activity in East Germany'. The methodology to generate the quarterly information for Eastern Germany is a bit different to the one used in the case of Saxony and Baden-Wuerttemberg. According to Brautzsch and Ludwig (2002) the quarterly data are generated by their so-called extrapolation method. The basis for disaggregation is not a stable regression relationship between annual information and a suitable indicator as in the case of Chow and Lin (1971), but rather the usage of quarterly shares in the annual aggregate. Both methods have the usage of high-frequency indicators in common. As for Saxony and Baden-Wuerttemberg, the IWH applies German national accounts data if regional information are missing. To compare the results for Eastern Germany with those for Saxony and Baden-Wuerttemberg, we also use real quarterly GDP data for the period from 1997Q1 to 2013Q4 that are seasonally adjusted and transformed into year-on-year growth rates afterwards.

\footnotetext{
${ }^{3}$ The latest data for Baden-Wurttemberg are available upon request from vgr@stala.bw.de.

${ }^{4}$ The data can be downloaded free of charge under http://www.iwh-halle.de/c/start/prognose/ download.asp?lang=e
} 
Our set of monthly indicators for Eastern Germany consists of 202 variables. The German and international information remain the same and we can add 37 regional indicators. We again do not take the indicators that are used for disaggregation into account. The same transformation as in the two cases before is applied to the monthly indicators for Eastern Germany.

\subsection{Boosting Algorithm}

In this paper we apply the component-wise $L_{2}$-boosting approach also used in the corresponding literature (see Buchen and Wohlrabe, 2011, 2014; Lehmann and Wohlrabe, 2016; Pierdzioch et al., 2016, 2015). Generally, boosting follows the idea of iteratively estimating an unknown function in either a linear or nonlinear manner. In applications with large data sets where the number of indicators exceeds the time dimension $(N \geq T)$, the complexity of the chosen fitting procedure has to be reduced by a pre-selection of variables (Bühlmann and $\mathrm{Yu}, 2003$ ). Standard statistical models such as ordinary least squares (OLS) rapidly lose their ability to estimate parameters in such large data set applications. With componentwise boosting we approximate the 'true' model by sequentially estimating nested models that, in the end, are summed up to a generalized model in additive form (forward stage-wise modelling):

$$
\widehat{f}_{M}\left(\mathbf{z}_{t}\right)=y_{t}=\bar{y}+\sum_{m=1}^{M} b\left(\mathbf{z}_{t} ; \widehat{\beta}_{m}\right),
$$

where the dependent variable to be forecasted is $y_{t}$. The number of iteration steps, and therefore the number of nested models to be estimated, is denoted by $m=1,2, \ldots, M$ and $b\left(\mathbf{z}_{t} ; \widehat{\beta}_{m}\right)$ is called 'learner'. $\mathbf{z}_{t}$ is the vector with all possible predictors and the corresponding parameter estimates are presented by $\widehat{\beta}_{m}$. For the $m$-th step, boosting adds the learner with the highest fit to the model from the previous iteration $\widehat{f}_{m-1}\left(\mathbf{z}_{t}\right)$ according to a specific loss function $L\left(y_{t}, \widehat{f}_{m}\left(\mathbf{z}_{t}\right)\right)$ and without modifying the already estimated parameters.

There are three questions that can immediately be raised from the previous description. How does the fitting procedure work? How is the 'learner' constructed? And how does the loss function look like? These questions are answered subsequently. As indicated at the beginning of this section, we apply component-wise $L_{2}$-boosting. In this context, componentwise means that in each iteration step not a function of predictors $\mathbf{z}_{t}$ is added to the model, but rather one single predictor $z_{t}$ from the pool of possible predictors (Bai and $\mathrm{Ng}, 2009$; Buchen and Wohlrabe, 2014). We use the squared error loss $\left(L_{2}\right.$-loss $)$ that is common in the literature. By applying the squared error loss, the learner is just iteratively fitted to the residuals $u_{t}$ from the previous stage: 


$$
\begin{aligned}
L\left(y_{t}, \widehat{f}_{m}\left(z_{t}\right)\right) & =1 / 2\left(y_{t}-\widehat{f}_{m}\left(z_{t}\right)\right)^{2} \\
& =1 / 2\left(y_{t}-\widehat{f}_{m-1}\left(z_{t}\right)-b\left(z_{t} ; \widehat{\beta}\right)\right)^{2} \\
& =1 / 2\left(u_{t}-b\left(z_{t} ; \widehat{\beta}\right)\right)^{2} .
\end{aligned}
$$

Before we turn to the description of the boosting-algorithm, we introduce the set of potential predictors $\mathbf{z}_{t}^{r}$ for each regional entity $r$ (Saxony [SX], Baden-Wuerttemberg [BW] and Eastern Germany [EG]). The vector $\mathbf{z}_{t}^{r}$ comprises $p$ lags of the target variable to predict $\left(y_{t-p}^{r}\right)$ as well as $p$ lags of all $N^{r}$ potential exogeneous predictors $\left(x_{N^{r}, t-p}^{r}\right)$. The number of potential exogeneous variables that can enter the model for each region were introduced in the former subsection and take the following values: $N^{S X}=234, N^{B W}=201$ and $N^{E G}=202$. From the pool of $z_{i, t}^{r}=1,2, \ldots, i, \ldots, p\left(1+N^{r}\right)$ potential predictors, the algorithm chooses in every iteration $m$ one 'optimal' variable $z_{i_{m}^{*}, t}^{r}$ that yields the smallest sum of squared residuals (SSR). But it is worth noting that the chosen predictor in a specific iteration does not have to be necessarily different from those of previous iterations, thus, one indicator can be added in linear form more than once. To be more concrete, the algorithm proceeds as follows:

1. Set $m=0$ and initialize the algorithm with the simple average of the target series $\widehat{f}_{0}^{r}\left(\mathbf{z}_{t}\right)=\bar{y}^{r}$.

2. For each iteration step $m=1$ to $M$ repeat:

(a) Calculate the actual residuals $u_{m, t}^{r}=y_{m-1, t}^{r}-\widehat{f}_{m-1}^{r}\left(\mathbf{z}_{t}\right)$.

(b) For $z_{i_{m}, t}^{r}=1,2, \ldots, i, \ldots p\left(1+N^{r}\right)$, regress the residuals $u_{m, t}^{r}$ on $z_{i_{m}, t}^{r}$ and compute the $S S R_{i_{m}}^{r}=\sum_{t=1}^{T}\left(u_{m, t}^{r}-b\left(z_{i_{m}, t}^{r} ; \widehat{\beta}_{i_{m}}^{r}\right)\right)^{2}$.

(c) Choose the 'optimal' indicator $z_{i_{m}^{*}, t}^{r}$ that yields the smallest sum of squared residuals: $S S R_{i_{m}^{*}}^{r}=\min S S R_{i_{m}}^{r}$.

(d) Update $\widehat{f}_{m}^{r}\left(\mathbf{z}_{t}\right)=\widehat{f}_{m-1}^{r}\left(\mathbf{z}_{t}\right)+\nu^{r} b\left(z_{i_{m}^{*}, t}^{r} ; \widehat{\beta}_{i_{m}^{*}}^{r}\right)$, with $0<\nu^{r}<1$. The 'learner' from the previous iteration step is left untouched.

Friedman (2001) first introduces $\nu^{r}$ as an additional regularization parameter next to $M$. The main reason for the introduction is to reduce the learner's variance, thus, improving the prediction performance of boosting. The algorithm converges to a function that represents the sum of $M$ base learner estimates multiplied by the constant shrinkage parameter $\nu^{r}$ :

$$
\widehat{f}_{M}^{r}\left(\mathbf{z}_{t}\right)=\bar{y}^{r}+\sum_{m=1}^{M} \nu^{r} b\left(z_{i_{m}^{*}, t}^{r} ; \widehat{\beta}_{i_{m}^{*}}^{r}\right) .
$$

From Equation (3) one can immediately see why boosting can handle large data sets. This equation cannot be estimated with standard techniques, but applying the boosting algorithm 
enables us to densify the most relevant information for forecasting from the pool of indicators $\mathbf{z}_{t}^{r}$. All variables that are not selected by the algorithm obtain a zero restriction on their coefficient. As one can see, the number of iteration steps can be arbitrary chosen. Thus, we need to find a rule in order to calculate the optimal number of iteration steps $M^{*}$. The most commonly used rules in the existing literature that minimize the expected forecast errors are cross-validation or information criteria (for example, the corrected Akaike Information Criterion). How the forecasting model looks like and which parameter we choose in practice, is described in the next subsection.

\subsection{Forecasting Approach}

After the introduction of the boosting algorithm in general, we describe the applied forecasting framework in the following. As in Buchen and Wohlrabe (2014) we apply ordinary least squares (OLS) for a linear model as the base 'learner' $b\left(z_{i, t}^{r} ; \beta_{i}^{r}\right)$. We restrict our analysis to allow only a one-period $\operatorname{lag}^{5}$ of $y^{r}$ and $\mathbf{z}^{r}$, thus, $p=1$. Taking the parameters and the setting together, our boosting model ends up in a boosted autoregressive distributed lag (ADL) model of the following form:

$$
\begin{aligned}
y_{t}^{r}= & \widehat{\alpha}^{r}+\sum_{m=1}^{M} \nu^{r} \widehat{\beta}_{i_{m}^{*}}^{r} z_{i_{m}^{*}, t-h}^{r}+\varepsilon_{t}^{r} \\
= & \widehat{\alpha}^{r}+\sum_{m=1}^{M} \nu^{r} \widehat{\gamma}_{i_{m}^{*}}^{r} y_{i_{m}^{*}, t-h}^{r}+\sum_{m=1}^{M} \nu^{r} \widehat{\delta}_{i_{m}^{*}}^{r} x_{i_{m}^{*}, t-h}^{r}+\varepsilon_{t}^{r} \\
& \text { with } i^{*} \in\left\{1, \ldots,\left(1+N^{r}\right)\right\} \text { and } \widehat{\gamma}_{i_{m}^{*}}^{r}, \widehat{\delta}_{i_{m}^{*}}^{r} \in \widehat{\beta}_{i_{m}^{*}}^{r} .
\end{aligned}
$$

The forecasting horizon for the three target series is denoted by $h$, which we restrict to $h \in\{1,2\}$, since most of the variables are short-term indicators. ${ }^{6}$ Because of the shortness of the data sets, we apply an pseudo out-of-sample expanding window approach, thus, the initial estimation window ranging from 1997Q1 to 2005Q4 $\left(T_{E}=36\right)$ is successively enlarged by one quarter in every timely iteration. After the enlargement each parameter is re-estimated and the algorithm is newly applied. The forecasting experiment is implemented in a direct-step fashion, thus, the forecasting equation is adjusted in such a way that forecasts for $h=2$ do not depend on forecasts for $h=1$. We, therefore, generate $T_{F}=32$ forecasts for both horizons. The first forecast is obtained for 2006Q1; the last forecast is calculated for 2013Q4. For each regional entity, the regularization parameter is set to $\nu^{r}=\nu=0.1$, which is fairly standard in the existing literature. The maximum number of boosting iterations $M^{r}$ for each region is selected by us via a small 'simulation study'. In the range of $M \in\{1,2, \ldots, 100\}$,

\footnotetext{
${ }^{5}$ We also experimented with a maximum of $p=4$, but the resulting forecast errors were larger compared to the ones produced with only one lag.

${ }^{6}$ For forecast horizons of three- or four-quarter-ahead $(h=3,4)$ we found that boosting looses its power compared to the benchmark model.
} 
we choose that $M$ where the algorithm produces the lowest forecast error for $h=1$. Because of the shortness of the time series and the regional focus of our study, no study in style of Buchen and Wohlrabe (2014) exists that recommends a maximum number of iterations. The 'simulation study' reveals the following maximum number of iterations: $M^{S X}=25$, $M^{B W}=100$ and $M^{E G}=30$. In the end, the optimal model is selected according to the corrected Akaike Information Criterion (see Buchen and Wohlrabe, 2014; Bühlmann, 2006). ${ }^{7}$

As the benchmark model, by which we assess the performance of boosting, we choose a boosted autoregressive process of order one:

$$
y_{t}^{r}=\widehat{\alpha}^{r}+\sum_{m=1}^{M} \nu^{r} \widehat{\beta}_{i_{m}^{*}}^{r} y_{i_{m}^{*}, t-h}^{r}+\varepsilon_{t}^{r} .
$$

An autoregressive benchmark is pretty standard in the forecasting literature, thus, our results are comparable with existing studies. ${ }^{8}$ As the measure of forecast accuracy, we apply the root mean squared forecast error (RMSFE). Let $F E_{t+h}^{r, \text { Boost }}=y_{t+h}^{r}-\widehat{y}_{t+h}^{r, \text { Boost }}$ denote the $h$-step-ahead forecast error resulting from boosting for regional GDP $\left(y^{r}\right)$ and period $t$, then the $R M S F E_{h}^{r, \text { Boost }}$ is defined as:

$$
R M S F E_{h}^{r, \text { Boost }}=\sqrt{\frac{1}{T_{F}} \sum_{k=1}^{T_{F}}\left(F E_{t+h, k}^{r, B o s t}\right)^{2}} .
$$

The respective RMSFE for the benchmark model is $R M S F E_{h}^{r, A R(1)}$. In order to decide whether boosting is performing better than the autoregressive process, we calculate the relative RMSFE (rRMSFE):

$$
r R M S F E_{h}^{r}=\frac{R M S F E_{h}^{r, \text { Boost }}}{R M S F E_{h}^{r, A R(1)}} .
$$

If this ratio is smaller than one, boosting with a large set of indicators produces lower forecast errors compared to the benchmark model on average. The opposite holds for ratios larger one.

\section{Results}

\subsection{General results}

We start by presenting the overall performance of boosting for the three regions under consideration. Table 1 shows the RMSFE (in percentage points) for boosting and the benchmark

\footnotetext{
${ }^{7}$ Cross-validation is an alternative of obtaining the optimal model. However, our small sample prevents us from using this selection criterion.

${ }^{8}$ Nevertheless, other benchmarks are also imaginable, for example, a random walk or a boosted autoregressive process with a higher order than one. Since we implement the boosting algorithm with a maximum number of one lag, the boosted autoregressive process of order is the fairest competitor.
} 
model as well as the resulting rRMSFE for both forecast horizons and the three regional entities. A rRMSFE smaller than one is set in bold face.

Table 1: Overall performance of boosting

\begin{tabular}{|c|c|c|c|c|c|c|}
\hline \multirow{2}{*}{ Region } & \multicolumn{3}{|c|}{$\mathbf{h}=\mathbf{1}$} & \multicolumn{3}{|c|}{$\mathbf{h}=\mathbf{2}$} \\
\hline & $\begin{array}{c}\text { Boosting } \\
\text { (RMSFE) }\end{array}$ & $\begin{array}{c}\text { Benchmark } \\
\text { (RMSFE) }\end{array}$ & $\begin{array}{c}\text { Ratio } \\
(\mathrm{rRMSFE})\end{array}$ & $\begin{array}{c}\text { Boosting } \\
\text { (RMSFE) }\end{array}$ & $\begin{array}{c}\text { Benchmark } \\
\text { (RMSFE) }\end{array}$ & $\begin{array}{c}\text { Ratio } \\
\text { (rRMSFE) }\end{array}$ \\
\hline Free State of Saxony & 1.908 & 2.135 & 0.894 & 2.812 & 2.753 & 1.021 \\
\hline Baden-Wuerttemberg & 2.319 & 3.284 & 0.706 & 3.893 & 5.139 & 0.757 \\
\hline Eastern Germany & 1.585 & 2.008 & 0.790 & 2.291 & 2.562 & 0.894 \\
\hline
\end{tabular}

With the exception of $h=2$ in the Saxon case $(r R M S F E=1.021)$, boosting outperforms the autoregressive benchmark model. The largest improvement over the benchmark can be found for Baden-Wuerttemberg for the shorter forecast horizon ( $R$ RMSFE =0.706). As indicated in Footnote 6 we also tested the performance of boosting for forecast horizons up to one year $(h=3,4)$. The two ratios for Saxony and Eastern Germany are larger than one. Only for Baden-Wuerttemberg boosting is able to beat the autoregressive benchmark for longer forecast horizons.

In the next step we ask whether there are region-specific indicators that get regularly selected by the algorithm. We can generally state that the composition of best indicators varies with the forecast horizon. However, there are indicators that show up for almost all horizons. At the opposite end of the scale, we have indicators in the sample such as price indices that never get selected by the procedure. ${ }^{9}$ In order to determine the most frequently chosen indicators, we introduce Table 2 that shows the top 10 for each forecast horizon and region. Each top-10-indicator is assigned a percentage value that can be interpreted as follows. The percentage value presents the cumulative frequency of an indicator that has been chosen by the boosting algorithm. Thus, it runs from $0 \%$ to $100 \%$. If an indicator gets chosen in period $t \in T_{F}$, then the cumulative frequency rises by $1 / 32$, with 32 as the length of our forecasting period $\left(T_{F}\right)$. An indicator's total frequency is then the sum of all forecasting steps where the indicator is part of the boosting model, divided by the length of the evaluation period.

In general, we find remarkable differences in the indicator selection for the three regional entities. However, there are some 'overlapping' indicators that provide forecasting signals for at least two of the three regions. First, the Composite Leading Indicators by the OECD, especially the one for China, get selected by the algorithm in the Saxon and Eastern German case. Second, indicators from the sector of construction play a crucial role for economic forecasting for Saxon and Eastern German GDP. This finding is triggered by the economic

\footnotetext{
${ }^{9} \mathrm{~A}$ complete list of all indicators for each regional entity and their relative frequency can be found in the Appendix.
} 
structure of both regions and we will elaborate more on this issue in the following subsections. Third, indicators from the industrial sector of automotive engineering get selected in all three regional cases. This is due to the fact that automotive engineering is the key branch in Germany, with firms like BMW, Mercedes and Volkswagen. We will discuss the region-specific results in more detail in the following subsections, compare these results with those found in existing studies and bring forward explanations why differences or similarities emerge.

Table 2: Top 10 indicators for each region and forecast horizon

\begin{tabular}{|c|c|c|c|}
\hline \multicolumn{2}{|l|}{$h=1$} & \multicolumn{2}{|l|}{$h=2$} \\
\hline \multicolumn{4}{|c|}{ Free State of Saxony } \\
\hline gross domestic product: SX & $100.0 \%$ & ifo SX: busin. expect. wholesale trade & $78.1 \%$ \\
\hline new orders: industr. construct. Saxony & $90.6 \%$ & UK average brent oil price & $59.4 \%$ \\
\hline ifo SX: busin. expect. wholesale trade & $75.0 \%$ & new orders: consumer goods & $56.3 \%$ \\
\hline new orders: consumer goods & $62.5 \%$ & Composite Leading Indicator: China & $56.3 \%$ \\
\hline Composite Leading Indicator: China & $62.5 \%$ & ifo SX: busin. climate chemicals & $56.3 \%$ \\
\hline Composite Leading Indicator: US & $59.4 \%$ & new orders: motor veh., trail. etc., dom. & $43.8 \%$ \\
\hline new orders: motor veh., trail. etc., dom. & $37.5 \%$ & new orders: chemicals, dom. & $40.6 \%$ \\
\hline industr. production: construct. & $28.1 \%$ & turnover: industr. construct. SX & $34.4 \%$ \\
\hline turnover: industr. construct. SX & $21.9 \%$ & new car registrations & $31.3 \%$ \\
\hline turnover: energy supply, dom. & $18.8 \%$ & vacancies total & $31.3 \%$ \\
\hline \multicolumn{4}{|c|}{ Baden-Wuerttemberg } \\
\hline vacancies total & $100.0 \%$ & vacancies total & $100.0 \%$ \\
\hline number of working days & $96.9 \%$ & ifo: production expect. consumer dur. & $100.0 \%$ \\
\hline new orders: consumer goods, fgn. & $90.6 \%$ & number of working days & $84.4 \%$ \\
\hline ifo: production expect. consumer dur. & $90.6 \%$ & new car registrations & $68.8 \%$ \\
\hline industr. production: consumer dur. & $84.4 \%$ & turnover: energy supply, fgn. & $62.5 \%$ \\
\hline new orders: consumer goods & $81.3 \%$ & new orders: motor veh., trail. etc., dom. & $62.5 \%$ \\
\hline new orders: public construct. BW & $81.3 \%$ & new orders: total manuf., fgn. & $62.5 \%$ \\
\hline ifo BW: busin. expect. retail sales & $71.9 \%$ & EU busin. survey: price expect. manuf. & $59.4 \%$ \\
\hline new orders: motor veh., trail. etc., fgn. & $68.8 \%$ & ifo BW: busin. expect. retail sales & $59.4 \%$ \\
\hline EU busin. survey: confid. indic. ret. sal. & $68.8 \%$ & working hours: industr. construct. BW & $59.4 \%$ \\
\hline \multicolumn{4}{|c|}{ Eastern Germany } \\
\hline Composite Leading Indicator: US & $100.0 \%$ & vacancies total & $93.8 \%$ \\
\hline vacancies total & $96.9 \%$ & Composite Leading Indicator: China & $59.4 \%$ \\
\hline Composite Leading Indicator: OECD & $71.9 \%$ & ifo: production expect. consumer dur. & $53.1 \%$ \\
\hline industr. production: construct. & $65.6 \%$ & turnover: consumer non-dur., dom. & $50.0 \%$ \\
\hline gross domestic product: EG & $62.5 \%$ & new car registrations & $50.0 \%$ \\
\hline Composite Leading Indicator: China & $62.5 \%$ & Composite Leading Indicator: US & $50.0 \%$ \\
\hline new orders: consumer goods & $59.4 \%$ & Composite Leading Indicator: OECD & $43.8 \%$ \\
\hline ifo: production expect. consumer dur. & $50.0 \%$ & new orders: motor veh., trail. etc., dom. & $40.6 \%$ \\
\hline retail sales: cars & $43.8 \%$ & new orders: industr. construct. EG & $34.4 \%$ \\
\hline Composite Leading Indicator: Asia & $40.6 \%$ & EU busin. survey: price expect. manuf. & $28.1 \%$ \\
\hline
\end{tabular}




\subsection{Free State of Saxony}

The most frequent selected indicator for $h=1$ are the autoregressive terms of the target variable, followed by new orders of Saxon industrial construction firms and the Ifo business expectations for Saxon wholesaling. Thus, regional indicators dominate the 'forecasting picture' for the Free State. We find similar results as in Lehmann and Wohlrabe (2014a) and Henzel et al. (2015), where the Ifo business expectations for Saxon wholesaling played a crucial role in forecasting total Saxon gross value added. Additionally, the construction sector is traditionally overrepresented in Eastern German states since large infrastructural investments were introduced after reunification (see Ragnitz, 2005) leading to a construction 'boom'. This may describe why indicators from the Saxon construction sector frequently get selected by the algorithm. Another interesting result is that domestic new orders of motor vehicles and trailers in Germany get frequently selected by the algorithm for $h=1$. Such a result is straightforward and in line with the structure of the Saxon economy. Vehicle manufacturing is the most important sector for the Saxon economy. In 2014, almost $30 \%$ of total Saxon industrial turnover was generated in the vehicle manufacturing sector. Unfortunately, official statistics provide no long time series on new orders of the Saxon vehicle manufacturing sector. We suggest that such an indicator will be selected very frequently by the algorithm.

For $h=2$ the most frequent selected indicator is again the Ifo business expectations for the Saxon wholesale trade, which reinforces the important role of regional indicators. Domestic new orders of motor vehicles and trailers in Germany are again among the top 10 indicators; we additionally find that new car registrations get frequently selected, which strengthens the argument on the structure of the Saxon economy. Next to vehicle manufacturing also regional survey results from the chemical industry in Saxony as well as new orders for German chemical products are part of the boosting model. This result is also straightforward, since the chemical industry has the fifth largest share (over 5\% in 2014) of total manufacturing turnover in Saxony. The last important indicator, which is also among the top five for $h=1$, is the OECD Composite Leading Indicator (CLI) for China. The People's Republic of China plays a crucial role for Saxon firms. In 2014, almost $18 \%$ of all Saxon exports were demanded by China, followed by the United States with a share of approximately $10 \%$ and Poland with 5\%. In general, the Saxon economy has the highest export quota $(2014: \approx 38 \%$ of total turnover in manufacturing were generated abroad) among the Eastern German states. These results are also in line with Henzel et al. (2015).

\subsection{Baden-Wuerttemberg}

The top 3 selected indicators for $h=1$ are total vacancies, the number or working days and foreign new orders of consumer goods. Compared to the study of Lehmann and Wohlrabe (2015), the results are somewhat different. The explanation is, however, straightforward. 
First, we use year-on-year growth rates instead of quarter-on-quarter growth rates in this study. And second, the time period under investigation varies. To the best of our knowledge, no other study exists to which we can compare our results. Among the top 10 indicators for $h=1$ we find foreign new orders for German vehicle manufacturing. The Daimler AG is located in Baden-Wuerttemberg, which describes this emerging result. In comparison to Saxony, regional indicators are not that dominant. One possible explanation is that important industrial indicators such as production are missing at the regional level. We expect that especially these missing indicators deliver important forecasting signals.

The top 3 indicators for $h=2$ are almost the same as for the shorter forecast horizon. Now, the Ifo production expectations for consumer durables always get selected by the indicator. Again, the vehicle manufacturing sector, together with new car registrations, are among the top 10 indicators. These findings can also be explained by the presence of the Daimler AG in Stuttgart, the capital city of Baden-Wuerttemberg. This view is also supported by new orders from abroad in total manufacturing. The economic structure of Baden-Wuerttemberg also delivers important hints for this result. With more than 30\% since 2010, Baden-Wuerttemberg has the highest share of manufacturing in gross value added among the German states. Next to vehicle manufacturing, capital goods producers with a high potential for new innovations such as the Bosch Group are located in the German state Baden-Wuerttemberg.

\subsection{Eastern Germany}

Turning to the last region of Eastern Germany, we find that the CLI for the US and OECD as well as total vacancies build the top 3 indicators for $h=1$. One of the most frequent selected indicators is industrial production in the construction sector. As stated in the 'General results' section, the Eastern German economy faced a construction 'boom' after reunification that led to an important position of the construction sector afterwards (Ragnitz, 2005). Another important results is the emergence of new orders of consumer goods. This is described by the key markets of Eastern German firms: they mainly operate on domestic markets and show a lower export quota compared to Western German firms (Ragnitz, 2009).

For $h=2$ the most relevant indicators are total vacancies, the OECD CLI for China and the Ifo production expectations for consumer durables. As for the Free State of Saxony, China holds an important position for the Eastern German exports. In 2014, almost 10\% of all Eastern German exports were demanded by China (for comparison: Western Germany $\approx 7 \%$, Baden-Wuerttemberg $\approx 8 \%$ ). This important position of China may explain why the CLI also gets selected by the algorithm in the Eastern German case. The last interesting results, for which we also find a suitable explanation, is the selection of new orders for Eastern German industrial construction firms. Next to the argumentation mentioned earlier and brought forward by Ragnitz (2005), the importance of industrial construction in Eastern 
Germany becomes obvious by looking at turnover figures. In 2014, industrial construction had the largest share in total Eastern German turnovers in 2014 (more than 37\%). Public construction had a share of almost $33 \%$ and building construction of nearly $30 \%$. Together with the fact that the share of construction in total gross value added in 2014 was $7 \%$ in Eastern Germany and $4 \%$ in the Western part, these turnover figures underpin the important position of construction for Eastern German economic development. Such a fact should be kept in mind if it comes to forecasting Eastern German GDP in practice.

\section{Conclusion}

With boosting we are able to calculate more precise forecasts of GDP for three German regions separately compared to a simple benchmark model. A closer look into the boosting procedure reveals interesting results for regional economic forecasting and therefore practitioner. Especially regional indicators that mirror the region-specific economic structure regularly get selected by the algorithm. However, a large number of variables, such as price indices, are never part of the boosting model.

Classical business cycle indicators such as GDP come with one disadvantage at the regional level: a low frequency. Or they are, in the case of industrial production, completely missing. A viable alternative can be labor market indicators such as employment development or unemployment rates. Future research activities can concentrate on these variables since we hypothesize that different indicators play a crucial role compared to GDP. If the focus of regional forecasters lie on labor market outcomes, a systematic study that applies boosting seems fruitful.

Another field of research can concentrate on different methodological issues. By investigating regional entities, we quickly think in terms of spatial applications such as spatial lag or spatial error models. Since boosting is a pure time series approach, future research activities can investigate methodological comparisons. How does boosting perform compared to simple spatial models? Is there any cross-section time-dimension trade-off for which one method is superior to the other? Such questions can also easily extended by other methods such as pooling or factor models.

Acknowledgments. We thank Udo Ludwig for his very helpful comments and Lisa Giani Contini for editing this text. 


\section{References}

Andrada-FÉlix, J. and Fernández-Rodríguez, F. (2008). Improving Moving Average Trading Rules with Boosting and Statistical Learning Methods. J. Forecast., 27 (5), 433449.

BAI, J. and NG, S. (2009). Boosting diffusion indices. J. Appl. Econ., 24 (4), 607-629.

Brautzsch, H.-U. and Ludwig, U. (2002). Vierteljährliche Entstehungsrechnung des Bruttoinlandsprodukts für Ostdeutschland: Sektorale Bruttowertschöpfung. IWHDiskussionspapier No. 164.

Buchen, T. and Wohlrabe, K. (2011). Forecasting with many predictors: Is boosting a viable alternative? Econ. Lett., 113 (1), 16-18.

— and - (2014). Assessing the Macroeconomic Forecasting Performance of Boosting Evidence for the United States, the Euro Area, and Germany. J. Forecast., 33 (4), 231242.

Bühlmann, P. (2006). Boosting for high-dimensional linear models. Ann. Stat., 34 (2), $559-583$.

Bühlmann, P. and Yu, B. (2003). Boosting with the $L_{2}$ loss: Regression and Classification. J. Am. Stat. Assoc., 98 (462), 324-339.

Chow, G. C. and Lin, A. (1971). Best Linear Unbiased Interpolation, Distribution and Exploration of Time Series by Related Series. Rev. Econ. Stat., 53 (4), 372-375.

Efron, B., Hastie, T., Johnstone, I. and Tibshirani, R. (2004). Least Angle Regression. Ann. Stat., 32 (2), 407-499.

Friedman, J. H. (2001). Greedy Function Approximation: A Gradient Boosting Machine. Ann. Stat., 29 (5), 1189-1232.

Henzel, S. R., Lehmann, R. and Wohlrabe, K. (2015). Nowcasting Regional GDP: The Case of the Free State of Saxony. Rev. Econ., 66 (1), 71-98.

Kim, H. H. and Swanson, N. R. (2014). Forecasting financial and macroeconomic variables using data reduction methods: New empirical evidence. J. Econ., 178 (2), 352-367.

Lehmann, R. and Wohlrabe, K. (2014a). Forecasting gross value-added at the regional level: are sectoral disaggregated predictions superior to direct ones? Rev. Reg. Res., 34 (1), $61-90$.

- and - (2014b). Regional economic forecasting: state-of-the-art methodology and future challenges. Econ. Bus. Lett., 3 (4), 218-231. 
- and - (2015). Forecasting GDP at the Regional Level with Many Predictors. Ger. Econ. Rev., 16 (2), 226-254.

- and - (2016). Looking into the black box of boosting: the case of Germany. Appl. Econ. Lett., 23 (17), 1229-1233.

Nierhaus, W. (2007). Vierteljährliche Volkswirtschaftliche Gesamtrechnungen für Sachsen mit Hilfe temporaler Disaggregation. ifo Dresden berichtet, 14 (4), 24-36.

Pierdzioch, C., Risse, M. and Rohloff, S. (2015). Forecasting gold-price fluctuations: a real-time boosting approach. Appl. Econ. Lett., 22 (1), 46-50.

— - - and - (2016). A boosting approach to forecasting gold and silver returns: economic and statistical forecast evaluation. Appl. Econ. Lett., 23 (5), 347-352.

Ragnitz, J. (2005). Fifteen years after: East Germany revisited. CESifo Forum, 6 (4), 3-6.

— (2009). East Germany Today: Successes and Failures. CESifo DICE Rep., 7 (4), 51-58.

Robinzonov, N., Tutz, G. and Hothorn, T. (2012). Boosting techniques for nonlinear time series models. AStA Adv. Stat. Anal., 96 (1), 99-122.

Vullhorst, U. (2008). Zur indikatorgestützten Berechnung des vierteljährlichen Bruttoinlandsprodukts für Baden-Württemberg. Statistisches Monatsheft Baden-Württemberg, 6, $32-35$.

ZEnG, J. (2016). Forecasting Aggregates with Disaggregate Variables: Does Boosting Help to Select the Most Relevant Predictors? J. Forecast., forthcoming. 


\section{A. Indicator List}

Table 3: List of indicators and cumulative frequency for the Free State of Saxony

\begin{tabular}{|c|c|c|}
\hline Indicator & $h=1$ & $\mathbf{h}=\mathbf{2}$ \\
\hline \multicolumn{3}{|l|}{ Target variable } \\
\hline gross domestic product (GDP): Free State of Saxony & $100.0 \%$ & $15.6 \%$ \\
\hline \multicolumn{3}{|l|}{ Macroeconomic variables } \\
\hline industrial production (IP): total (incl. construction) & $0.0 \%$ & $0.0 \%$ \\
\hline IP manufacturing: total & $0.0 \%$ & $0.0 \%$ \\
\hline IP manufacturing: intermediate goods & $0.0 \%$ & $0.0 \%$ \\
\hline IP manufacturing: consumer goods & $0.0 \%$ & $0.0 \%$ \\
\hline IP manufacturing: capital goods & $0.0 \%$ & $0.0 \%$ \\
\hline IP manufacturing: consumer durables & $3.1 \%$ & $0.0 \%$ \\
\hline IP manufacturing: consumer non-durables & $0.0 \%$ & $9.4 \%$ \\
\hline IP manufacturing: mining and quarrying & $0.0 \%$ & $0.0 \%$ \\
\hline IP manufacturing: chemicals & $0.0 \%$ & $0.0 \%$ \\
\hline IP manufacturing: basic metals & $0.0 \%$ & $0.0 \%$ \\
\hline IP manufacturing: mechanical engineering & $0.0 \%$ & $0.0 \%$ \\
\hline IP manufacturing: motor vehicles, trailers etc. & $0.0 \%$ & $0.0 \%$ \\
\hline IP construction: total & $28.1 \%$ & $6.3 \%$ \\
\hline IP energy supply: total & $0.0 \%$ & $0.0 \%$ \\
\hline turnover (TO): manufacturing total, domestic & $0.0 \%$ & $0.0 \%$ \\
\hline TO: manufacturing total, foreign & $0.0 \%$ & $0.0 \%$ \\
\hline TO: intermediate goods, domestic & $0.0 \%$ & $6.3 \%$ \\
\hline TO: intermediate goods, foreign & $0.0 \%$ & $0.0 \%$ \\
\hline TO: consumer goods, domestic & $0.0 \%$ & $0.0 \%$ \\
\hline TO: consumer goods, foreign & $0.0 \%$ & $0.0 \%$ \\
\hline TO: capital goods, domestic & $0.0 \%$ & $0.0 \%$ \\
\hline TO: capital goods, foreign & $0.0 \%$ & $0.0 \%$ \\
\hline TO: consumer durables, domestic & $0.0 \%$ & $0.0 \%$ \\
\hline TO: consumer durables, foreign & $0.0 \%$ & $0.0 \%$ \\
\hline TO: consumer non-durables, domestic & $0.0 \%$ & $0.0 \%$ \\
\hline TO: consumer non-durables, foreign & $0.0 \%$ & $0.0 \%$ \\
\hline TO: mining and quarrying, domestic & $3.1 \%$ & $0.0 \%$ \\
\hline TO: mining and quarrying, foreign & $0.0 \%$ & $0.0 \%$ \\
\hline TO: energy, gas etc. supply, domestic & $18.8 \%$ & $3.1 \%$ \\
\hline TO: energy, gas etc. supply, foreign & $0.0 \%$ & $6.3 \%$ \\
\hline TO: chemicals, domestic & $0.0 \%$ & $0.0 \%$ \\
\hline TO: chemicals, foreign & $0.0 \%$ & $0.0 \%$ \\
\hline TO: mechanical engineering, domestic & $0.0 \%$ & $0.0 \%$ \\
\hline TO: mechanical engineering, foreign & $0.0 \%$ & $0.0 \%$ \\
\hline TO: motor vehicles, trailers etc., domestic & $0.0 \%$ & $0.0 \%$ \\
\hline TO: motor vehicles, trailers etc., foreign & $0.0 \%$ & $0.0 \%$ \\
\hline TO: comp., electr. and opt. prod., domestic & $0.0 \%$ & $0.0 \%$ \\
\hline TO: comp., electr. and opt. prod., foreign & $0.0 \%$ & $0.0 \%$ \\
\hline new orders (NO): manufacturing total & $0.0 \%$ & $0.0 \%$ \\
\hline NO: manufacturing total, domestic & $3.1 \%$ & $6.3 \%$ \\
\hline NO: manufacturing total, foreign & $0.0 \%$ & $0.0 \%$ \\
\hline NO: intermediate goods & $0.0 \%$ & $0.0 \%$ \\
\hline NO: intermediate goods, domestic & $0.0 \%$ & $0.0 \%$ \\
\hline NO: intermediate goods, foreign & $0.0 \%$ & $0.0 \%$ \\
\hline NO: consumer goods & $62.5 \%$ & $56.3 \%$ \\
\hline NO: consumer goods, domestic & $0.0 \%$ & $0.0 \%$ \\
\hline
\end{tabular}


Table 3: List of indicators and cumulative frequency for the Free State of Saxony - continued

\begin{tabular}{|c|c|c|}
\hline Indicator & $\mathbf{h}=\mathbf{1}$ & $\mathbf{h}=\mathbf{2}$ \\
\hline NO: consumer goods, foreign & $0.0 \%$ & $0.0 \%$ \\
\hline NO: capital goods & $0.0 \%$ & $0.0 \%$ \\
\hline NO: capital goods, domestic & $0.0 \%$ & $0.0 \%$ \\
\hline NO: capital goods, foreign & $0.0 \%$ & $0.0 \%$ \\
\hline NO: chemicals, domestic & $0.0 \%$ & $40.6 \%$ \\
\hline NO: chemicals, foreign & $0.0 \%$ & $0.0 \%$ \\
\hline NO: mechanical engineering, domestic & $0.0 \%$ & $0.0 \%$ \\
\hline NO: mechanical engineering, foreign & $0.0 \%$ & $0.0 \%$ \\
\hline NO: motor vehicles, trailers etc., domestic & $37.5 \%$ & $43.8 \%$ \\
\hline NO: motor vehicles, trailers etc., foreign & $0.0 \%$ & $0.0 \%$ \\
\hline NO: comp., electr. and opt. prod., domestic & $0.0 \%$ & $0.0 \%$ \\
\hline NO: comp., electr. and opt. prod., foreign & $0.0 \%$ & $0.0 \%$ \\
\hline wholesale trade (WT): total employment & $0.0 \%$ & $0.0 \%$ \\
\hline retail sales (RS): turnover, total (excl. cars) & $6.3 \%$ & $9.4 \%$ \\
\hline new registrations $(\mathrm{NR})$ : all vehicles & $0.0 \%$ & $31.3 \%$ \\
\hline NR: cars & $0.0 \%$ & $0.0 \%$ \\
\hline NR: heavy trucks & $0.0 \%$ & $0.0 \%$ \\
\hline exports: volume index, basis 2005 & $0.0 \%$ & $0.0 \%$ \\
\hline imports: volume index, basis 2005 & $0.0 \%$ & $0.0 \%$ \\
\hline unemployed persons (UNP): total, $\%$ of civilian labor & $0.0 \%$ & $0.0 \%$ \\
\hline employed persons (EMPL): residence concept, total & $0.0 \%$ & $0.0 \%$ \\
\hline EMPL: work-place concept, total & $0.0 \%$ & $0.0 \%$ \\
\hline working days: total & $0.0 \%$ & $0.0 \%$ \\
\hline vacancies: total & $0.0 \%$ & $31.3 \%$ \\
\hline wages and salaries (WS): total economy, hourly basis & $0.0 \%$ & $0.0 \%$ \\
\hline WS: total economy, per employed person & $0.0 \%$ & $0.0 \%$ \\
\hline Euro-Coin real time estimates & $0.0 \%$ & $0.0 \%$ \\
\hline \multicolumn{3}{|l|}{ Prices } \\
\hline consumer price index & $0.0 \%$ & $0.0 \%$ \\
\hline consumer price index (excl. energy) & $0.0 \%$ & $0.0 \%$ \\
\hline producer price index & $0.0 \%$ & $0.0 \%$ \\
\hline wholesale trade price index, $1975=100$ & $0.0 \%$ & $0.0 \%$ \\
\hline export price index & $0.0 \%$ & $0.0 \%$ \\
\hline import price index & $0.0 \%$ & $0.0 \%$ \\
\hline HWWA index of world market prices: eurozone, energy & $3.1 \%$ & $0.0 \%$ \\
\hline HWWA index of world market prices: eurozone, excl. energy & $0.0 \%$ & $6.3 \%$ \\
\hline oil prices, euro per barrel & $0.0 \%$ & $0.0 \%$ \\
\hline UK average brent oil price & $0.0 \%$ & $59.4 \%$ \\
\hline London gold price, per US $\$$ & $18.8 \%$ & $28.1 \%$ \\
\hline \multicolumn{3}{|l|}{ Surveys } \\
\hline ZEW: economic sentiment indicator & $0.0 \%$ & $0.0 \%$ \\
\hline ZEW: present economic situation & $0.0 \%$ & $0.0 \%$ \\
\hline ifo business climate industry and trade & $0.0 \%$ & $0.0 \%$ \\
\hline ifo: assessm. of business situation industry and trade & $0.0 \%$ & $0.0 \%$ \\
\hline ifo: business expectations industry and trade & $0.0 \%$ & $0.0 \%$ \\
\hline ifo: business climate manufacturing & $0.0 \%$ & $0.0 \%$ \\
\hline ifo: assessment of business situation manufacturing & $0.0 \%$ & $0.0 \%$ \\
\hline ifo: business expectations manufacturing & $0.0 \%$ & $0.0 \%$ \\
\hline ifo: inventory of finished goods manufacturing & $0.0 \%$ & $0.0 \%$ \\
\hline ifo: orders on hand manufacturing & $0.0 \%$ & $0.0 \%$ \\
\hline ifo: foreign orders on hand manufacturing & $0.0 \%$ & $0.0 \%$ \\
\hline ifo: export expectations next 3 months manufacturing & $0.0 \%$ & $0.0 \%$ \\
\hline \multirow[t]{2}{*}{ ifo: business climate intermediate goods } & $0.0 \%$ & $0.0 \%$ \\
\hline & d on ne & page... \\
\hline
\end{tabular}


Table 3: List of indicators and cumulative frequency for the Free State of Saxony - continued

\begin{tabular}{|c|c|c|}
\hline Indicator & $\mathbf{h}=\mathbf{1}$ & $\mathbf{h}=\mathbf{2}$ \\
\hline ifo: assessm. of business sit. intermediate goods & $3.1 \%$ & $0.0 \%$ \\
\hline ifo: production expectations intermediate goods & $0.0 \%$ & $0.0 \%$ \\
\hline ifo: business climate consumer goods & $0.0 \%$ & $0.0 \%$ \\
\hline ifo: assessment of business situation consumer goods & $0.0 \%$ & $0.0 \%$ \\
\hline ifo: business expectations consumer goods & $0.0 \%$ & $0.0 \%$ \\
\hline ifo: business climate capital goods & $0.0 \%$ & $0.0 \%$ \\
\hline ifo: assessment of business situation capital goods & $0.0 \%$ & $0.0 \%$ \\
\hline ifo: production expectations capital goods & $0.0 \%$ & $0.0 \%$ \\
\hline ifo: business climate consumer durables & $0.0 \%$ & $0.0 \%$ \\
\hline ifo: assessment of business situation consumer durables & $0.0 \%$ & $0.0 \%$ \\
\hline ifo: production expectations consumer durables & $0.0 \%$ & $25.0 \%$ \\
\hline ifo: business climate consumer non-durables & $9.4 \%$ & $0.0 \%$ \\
\hline ifo: assessm. of business sit. consumer non-durables & $0.0 \%$ & $0.0 \%$ \\
\hline ifo: production expectations consumer non-durables & $6.3 \%$ & $3.1 \%$ \\
\hline ifo: business climate construction & $0.0 \%$ & $0.0 \%$ \\
\hline ifo: assessment of business situation construction & $0.0 \%$ & $0.0 \%$ \\
\hline ifo: business expectations construction & $0.0 \%$ & $0.0 \%$ \\
\hline ifo: construction unfavourable weather & $0.0 \%$ & $0.0 \%$ \\
\hline ifo: orders on hand construction & $0.0 \%$ & $0.0 \%$ \\
\hline ifo: business climate wholesale trade & $0.0 \%$ & $0.0 \%$ \\
\hline ifo: assessment of business situation wholesale trade & $0.0 \%$ & $0.0 \%$ \\
\hline ifo: business expectations wholesale trade & $0.0 \%$ & $0.0 \%$ \\
\hline ifo: assessment of inventories wholesale trade & $0.0 \%$ & $0.0 \%$ \\
\hline ifo: expect. with regard to order activ. next 3 months WT & $0.0 \%$ & $0.0 \%$ \\
\hline ifo: business climate retail sales & $0.0 \%$ & $0.0 \%$ \\
\hline ifo: assessment of inventories retail sales & $0.0 \%$ & $0.0 \%$ \\
\hline ifo: business expectations retail sales & $0.0 \%$ & $0.0 \%$ \\
\hline ifo: expect. with regard to order activ. next 3 months RS & $0.0 \%$ & $0.0 \%$ \\
\hline EU consumer survey (EUCS): unemploym. expect. next 12 months & $0.0 \%$ & $0.0 \%$ \\
\hline EUCS: statement on financial situation & $0.0 \%$ & $0.0 \%$ \\
\hline EUCS: consumer confidence indicator & $0.0 \%$ & $0.0 \%$ \\
\hline EUCS: economic sentiment indicator & $0.0 \%$ & $0.0 \%$ \\
\hline EU business survey (EUBS): product. trends recent month, ind. & $0.0 \%$ & $12.5 \%$ \\
\hline EUBS: assessment of order-book levels, industry & $0.0 \%$ & $0.0 \%$ \\
\hline EUBS: assessment of export oder-books level, industry & $0.0 \%$ & $0.0 \%$ \\
\hline EUBS: assessment of stocks of finished products, industry & $0.0 \%$ & $0.0 \%$ \\
\hline EUBS: production expectations for the month ahead, industry & $0.0 \%$ & $0.0 \%$ \\
\hline EUBS: selling price expectations for the month ahead, industry & $0.0 \%$ & $9.4 \%$ \\
\hline EUBS: employment expectations for the month ahead, industry & $0.0 \%$ & $0.0 \%$ \\
\hline EUBS: industrial confidence indicator & $0.0 \%$ & $0.0 \%$ \\
\hline EUBS: service sector confidence indicator & $0.0 \%$ & $0.0 \%$ \\
\hline EUBS: retail trade confidence indicator & $0.0 \%$ & $0.0 \%$ \\
\hline EUBS: construction confidence indicator & $0.0 \%$ & $0.0 \%$ \\
\hline \multicolumn{3}{|l|}{ International } \\
\hline Bulgarian business indicator survey, whole economy & $0.0 \%$ & $3.1 \%$ \\
\hline Bulgarian business indicator survey, manufacturing & $0.0 \%$ & $9.4 \%$ \\
\hline EUCS: economic sentiment indicator, France & $0.0 \%$ & $0.0 \%$ \\
\hline EUCS: economic sentiment indicator, Spain & $0.0 \%$ & $0.0 \%$ \\
\hline EUCS: economic sentiment indicator, Poland & $0.0 \%$ & $0.0 \%$ \\
\hline EUCS: economic sentiment indicator, Czech Republic & $0.0 \%$ & $0.0 \%$ \\
\hline EUCS: economic sentiment indicator, Italy & $0.0 \%$ & $0.0 \%$ \\
\hline EUCS: economic sentiment indicator, United Kingdom & $0.0 \%$ & $0.0 \%$ \\
\hline \multirow[t]{2}{*}{ University of Michigan consumer sentiment } & $0.0 \%$ & $0.0 \%$ \\
\hline & on ne & page... \\
\hline
\end{tabular}


Table 3: List of indicators and cumulative frequency for the Free State of Saxony - continued

\begin{tabular}{|c|c|c|}
\hline Indicator & $\mathbf{h}=\mathbf{1}$ & $\mathbf{h}=\mathbf{2}$ \\
\hline IP: United States, total & $0.0 \%$ & $0.0 \%$ \\
\hline OECD Composite Leading Indicator (CLI): OECD, ampl. adj. & $0.0 \%$ & $0.0 \%$ \\
\hline CLI: OECD, trend restored & $0.0 \%$ & $0.0 \%$ \\
\hline CLI: OECD, normalised & $15.6 \%$ & $0.0 \%$ \\
\hline CLI: Asia, amplitude adjusted & $0.0 \%$ & $0.0 \%$ \\
\hline CLI: Asia, trend restored & $0.0 \%$ & $0.0 \%$ \\
\hline CLI: Asia, normalised & $0.0 \%$ & $0.0 \%$ \\
\hline CLI: China, amplitude adjusted & $0.0 \%$ & $0.0 \%$ \\
\hline CLI: China, trend restored & $0.0 \%$ & $0.0 \%$ \\
\hline CLI: China, normalised & $62.5 \%$ & $56.3 \%$ \\
\hline CLI: Euro Area, amplitude adjusted & $0.0 \%$ & $0.0 \%$ \\
\hline CLI: Euro Area, trend restored & $0.0 \%$ & $0.0 \%$ \\
\hline CLI: Euro Area, normalised & $0.0 \%$ & $6.3 \%$ \\
\hline CLI: United States, amplitude adjusted & $6.3 \%$ & $0.0 \%$ \\
\hline CLI: United States, trend restored & $0.0 \%$ & $0.0 \%$ \\
\hline CLI: United States, normalised & $59.4 \%$ & $0.0 \%$ \\
\hline \multicolumn{3}{|l|}{ Regional } \\
\hline ifo business climate industry and trade, Saxony & $0.0 \%$ & $0.0 \%$ \\
\hline ifo SAX: assessm. of business situation industry and trade & $0.0 \%$ & $0.0 \%$ \\
\hline ifo SAX: business expectations industry and trade & $0.0 \%$ & $0.0 \%$ \\
\hline ifo SAX: business climate manufacturing & $0.0 \%$ & $0.0 \%$ \\
\hline ifo SAX: assessment of business situation manufacturing & $0.0 \%$ & $0.0 \%$ \\
\hline ifo SAX: business expectations manufacturing & $0.0 \%$ & $0.0 \%$ \\
\hline ifo SAX: export expectations manufacturing & $0.0 \%$ & $0.0 \%$ \\
\hline ifo SAX: business climate intermediate goods & $0.0 \%$ & $0.0 \%$ \\
\hline ifo SAX: assessm. of business sit. intermediate goods & $0.0 \%$ & $0.0 \%$ \\
\hline ifo SAX: business expectations intermediate goods & $0.0 \%$ & $0.0 \%$ \\
\hline ifo SAX: business climate consumer goods & $0.0 \%$ & $0.0 \%$ \\
\hline ifo SAX: assessment of business situation consumer goods & $0.0 \%$ & $0.0 \%$ \\
\hline ifo SAX: business expectations consumer goods & $0.0 \%$ & $0.0 \%$ \\
\hline ifo SAX: business climate capital goods & $0.0 \%$ & $0.0 \%$ \\
\hline ifo SAX: assessment of business situation capital goods & $0.0 \%$ & $0.0 \%$ \\
\hline ifo SAX: business expectations capital goods & $0.0 \%$ & $0.0 \%$ \\
\hline ifo SAX: business climate consumer non-durables & $0.0 \%$ & $0.0 \%$ \\
\hline ifo SAX: assessm. of business sit. consumer non-durables & $0.0 \%$ & $0.0 \%$ \\
\hline ifo SAX: business expectations consumer non-durables & $0.0 \%$ & $0.0 \%$ \\
\hline ifo SAX: business climate food, beverage and tobacco & $0.0 \%$ & $0.0 \%$ \\
\hline ifo SAX: assessm. of business sit. food, beverage and tobacco & $0.0 \%$ & $0.0 \%$ \\
\hline ifo SAX: business expectations food, beverage and tobacco & $0.0 \%$ & $28.1 \%$ \\
\hline ifo SAX: business climate chemicals & $0.0 \%$ & $56.3 \%$ \\
\hline ifo SAX: assessm. of business sit. chemicals & $12.5 \%$ & $0.0 \%$ \\
\hline ifo SAX: business expectations chemicals & $0.0 \%$ & $25.0 \%$ \\
\hline ifo SAX: business climate mechanical engineering & $6.3 \%$ & $0.0 \%$ \\
\hline ifo SAX: assessm. of business sit. mechanical engineering & $0.0 \%$ & $15.6 \%$ \\
\hline ifo SAX: business expectations mechanical engineering & $0.0 \%$ & $0.0 \%$ \\
\hline ifo SAX: business climate motor vehicles, trailers etc. & $0.0 \%$ & $0.0 \%$ \\
\hline ifo SAX: assessm. of business sit. motor vehicles, trailers etc. & $0.0 \%$ & $0.0 \%$ \\
\hline ifo SAX: business expectations motor vehicles, trailers etc. & $0.0 \%$ & $0.0 \%$ \\
\hline ifo SAX: business climate construction & $0.0 \%$ & $0.0 \%$ \\
\hline ifo SAX: assessment of business situation construction & $0.0 \%$ & $0.0 \%$ \\
\hline ifo SAX: business expectations construction & $0.0 \%$ & $0.0 \%$ \\
\hline ifo SAX: business climate building construction & $0.0 \%$ & $0.0 \%$ \\
\hline \multirow[t]{2}{*}{ ifo SAX: assessm. of business sit. building construction } & $0.0 \%$ & $0.0 \%$ \\
\hline & on ne & oage... \\
\hline
\end{tabular}


Table 3: List of indicators and cumulative frequency for the Free State of Saxony - continued

\begin{tabular}{lrr}
\hline Indicator & $\mathbf{h}=\mathbf{1}$ & $\mathbf{h}=\mathbf{2}$ \\
\hline ifo SAX: business expectations building construction & $0.0 \%$ & $0.0 \%$ \\
ifo SAX: business climate underground construction & $0.0 \%$ & $0.0 \%$ \\
ifo SAX: assessm. of business sit. underground construction & $0.0 \%$ & $0.0 \%$ \\
ifo SAX: business expectations underground construction & $0.0 \%$ & $0.0 \%$ \\
ifo SAX: employment expectations construction & $0.0 \%$ & $0.0 \%$ \\
ifo SAX: business climate wholesale trade & $3.1 \%$ & $0.0 \%$ \\
ifo SAX: assessment of business situation wholesale trade & $0.0 \%$ & $0.0 \%$ \\
ifo SAX: business expectations wholesale trade & $75.0 \%$ & $78.1 \%$ \\
ifo SAX: employment expectations wholesale trade & $0.0 \%$ & $0.0 \%$ \\
ifo SAX: business climate retail sales & $0.0 \%$ & $0.0 \%$ \\
ifo SAX: assessment of business situation retail sales & $0.0 \%$ & $0.0 \%$ \\
ifo SAX: business expectations retail sales & $0.0 \%$ & $0.0 \%$ \\
ifo SAX: employment expectations retail sales & $0.0 \%$ & $0.0 \%$ \\
turnover (TO): housing construction, Saxony & $0.0 \%$ & $0.0 \%$ \\
TO: commercial construction, Saxony & $21.9 \%$ & $34.4 \%$ \\
TO: public construction, Saxony & $0.0 \%$ & $0.0 \%$ \\
new orders (NO): manufacturing total, Saxony & $0.0 \%$ & $0.0 \%$ \\
NO: construction total, Saxony & $0.0 \%$ & $0.0 \%$ \\
NO: housing construction, Saxony & $0.0 \%$ & $0.0 \%$ \\
NO: commercial construction, Saxony & $90.6 \%$ & $3.1 \%$ \\
NO: public construction, Saxony & $12.5 \%$ & $0.0 \%$ \\
exports: values, Saxony & $0.0 \%$ & $3.1 \%$ \\
imports: values, Saxony & $0.0 \%$ & $0.0 \%$ \\
working hours (WH): construction total, Saxony & $0.0 \%$ & $0.0 \%$ \\
WH: housing construction, Saxony & $0.0 \%$ & $0.0 \%$ \\
WH: commercial construction, Saxony & $0.0 \%$ & $0.0 \%$ \\
WH: public construction, Saxony & $0.0 \%$ & $0.0 \%$ \\
number of firms, construction total, Saxony & $0.0 \%$ & $9.4 \%$ \\
number of employed persons, construction total, Saxony & $0.0 \%$ & $0.0 \%$ \\
compensations, construction total, Saxony & $0.0 \%$ & $0.0 \%$ \\
consumer price index, Saxony & $0.0 \%$ & $0.0 \%$ \\
capacity utilization, construction total, Saxony & $0.0 \%$ & $0.0 \%$ \\
range of orders on hand, construction total, Saxony & $0.0 \%$ & $0.0 \%$ \\
\hline Note: The tabe pron & & \\
\hline
\end{tabular}

Note: The table presents the relative frequencies of all indicators in our sample for the different forecasting horizons. A value of $100 \%$ is reached if an indicator gets chosen by the algorithm 32 times, thus, for the length of our forecasting period. An indicator is assigned with $0 \%$ if this indicator is not chosen over the forecasting period at all. 
Table 4: List of indicators and cumulative frequency for BadenWuerttemberg

\begin{tabular}{|c|c|c|}
\hline Indicator & $\mathbf{h}=\mathbf{1}$ & $\mathbf{h}=\mathbf{2}$ \\
\hline \multicolumn{3}{|l|}{ Target variable } \\
\hline gross domestic product (GDP): Baden-Wuerttemberg & $18.8 \%$ & $0.0 \%$ \\
\hline \multicolumn{3}{|l|}{ Macroeconomic variables } \\
\hline industrial production (IP): total (incl. construction) & $0.0 \%$ & $0.0 \%$ \\
\hline IP manufacturing: total & $0.0 \%$ & $0.0 \%$ \\
\hline IP manufacturing: intermediate goods & $0.0 \%$ & $0.0 \%$ \\
\hline IP manufacturing: consumer goods & $12.5 \%$ & $6.3 \%$ \\
\hline IP manufacturing: capital goods & $0.0 \%$ & $0.0 \%$ \\
\hline IP manufacturing: consumer durables & $84.4 \%$ & $6.3 \%$ \\
\hline IP manufacturing: consumer non-durables & $3.1 \%$ & $46.9 \%$ \\
\hline IP manufacturing: mining and quarrying & $0.0 \%$ & $0.0 \%$ \\
\hline IP manufacturing: chemicals & $0.0 \%$ & $0.0 \%$ \\
\hline IP manufacturing: basic metals & $0.0 \%$ & $0.0 \%$ \\
\hline IP manufacturing: mechanical engineering & $0.0 \%$ & $0.0 \%$ \\
\hline IP manufacturing: motor vehicles, trailers etc. & $0.0 \%$ & $0.0 \%$ \\
\hline IP construction: total & $9.4 \%$ & $0.0 \%$ \\
\hline IP energy supply: total & $3.1 \%$ & $0.0 \%$ \\
\hline turnover (TO): manufacturing total, domestic & $0.0 \%$ & $0.0 \%$ \\
\hline TO: manufacturing total, foreign & $0.0 \%$ & $0.0 \%$ \\
\hline TO: intermediate goods, domestic & $21.9 \%$ & $0.0 \%$ \\
\hline TO: intermediate goods, foreign & $0.0 \%$ & $0.0 \%$ \\
\hline TO: consumer goods, domestic & $12.5 \%$ & $6.3 \%$ \\
\hline TO: consumer goods, foreign & $0.0 \%$ & $0.0 \%$ \\
\hline TO: capital goods, domestic & $0.0 \%$ & $0.0 \%$ \\
\hline TO: capital goods, foreign & $0.0 \%$ & $0.0 \%$ \\
\hline TO: consumer durables, domestic & $25.0 \%$ & $12.5 \%$ \\
\hline TO: consumer durables, foreign & $0.0 \%$ & $0.0 \%$ \\
\hline TO: consumer non-durables, domestic & $3.1 \%$ & $25.0 \%$ \\
\hline TO: consumer non-durables, foreign & $0.0 \%$ & $0.0 \%$ \\
\hline TO: mining and quarrying, domestic & $0.0 \%$ & $0.0 \%$ \\
\hline TO: mining and quarrying, foreign & $0.0 \%$ & $0.0 \%$ \\
\hline TO: energy, gas etc. supply, domestic & $9.4 \%$ & $0.0 \%$ \\
\hline TO: energy, gas etc. supply, foreign & $46.9 \%$ & $62.5 \%$ \\
\hline TO: chemicals, domestic & $0.0 \%$ & $31.3 \%$ \\
\hline TO: chemicals, foreign & $0.0 \%$ & $0.0 \%$ \\
\hline TO: mechanical engineering, domestic & $0.0 \%$ & $37.5 \%$ \\
\hline TO: mechanical engineering, foreign & $21.9 \%$ & $0.0 \%$ \\
\hline TO: motor vehicles, trailers etc., domestic & $3.1 \%$ & $3.1 \%$ \\
\hline TO: motor vehicles, trailers etc., foreign & $9.4 \%$ & $0.0 \%$ \\
\hline TO: comp., electr. and opt. prod., domestic & $15.6 \%$ & $0.0 \%$ \\
\hline TO: comp., electr. and opt. prod., foreign & $0.0 \%$ & $0.0 \%$ \\
\hline new orders $(\mathrm{NO})$ : manufacturing total & $0.0 \%$ & $0.0 \%$ \\
\hline NO: manufacturing total, domestic & $0.0 \%$ & $0.0 \%$ \\
\hline NO: manufacturing total, foreign & $0.0 \%$ & $0.0 \%$ \\
\hline NO: intermediate goods & $0.0 \%$ & $0.0 \%$ \\
\hline NO: intermediate goods, domestic & $46.9 \%$ & $0.0 \%$ \\
\hline NO: intermediate goods, foreign & $0.0 \%$ & $0.0 \%$ \\
\hline NO: consumer goods & $81.3 \%$ & $6.3 \%$ \\
\hline NO: consumer goods, domestic & $0.0 \%$ & $3.1 \%$ \\
\hline NO: consumer goods, foreign & $90.6 \%$ & $56.3 \%$ \\
\hline NO: capital goods & $0.0 \%$ & $0.0 \%$ \\
\hline
\end{tabular}


Table 4: List of indicators and cumulative frequency for BadenWuerttemberg - continued

\begin{tabular}{|c|c|c|}
\hline Indicator & $h=1$ & $\mathbf{h}=\mathbf{2}$ \\
\hline NO: capital goods, domestic & $0.0 \%$ & $0.0 \%$ \\
\hline NO: capital goods, foreign & $0.0 \%$ & $0.0 \%$ \\
\hline NO: chemicals, domestic & $0.0 \%$ & $3.1 \%$ \\
\hline NO: chemicals, foreign & $0.0 \%$ & $0.0 \%$ \\
\hline NO: mechanical engineering, domestic & $0.0 \%$ & $6.3 \%$ \\
\hline NO: mechanical engineering, foreign & $0.0 \%$ & $0.0 \%$ \\
\hline NO: motor vehicles, trailers etc., domestic & $31.3 \%$ & $62.5 \%$ \\
\hline NO: motor vehicles, trailers etc., foreign & $68.8 \%$ & $12.5 \%$ \\
\hline NO: comp., electr. and opt. prod., domestic & $37.5 \%$ & $40.6 \%$ \\
\hline NO: comp., electr. and opt. prod., foreign & $3.1 \%$ & $0.0 \%$ \\
\hline wholesale trade $(\mathrm{WT})$ : total employment & $0.0 \%$ & $12.5 \%$ \\
\hline retail sales (RS): turnover, total (excl. cars) & $15.6 \%$ & $9.4 \%$ \\
\hline new registrations (NR): all vehicles & $3.1 \%$ & $9.4 \%$ \\
\hline NR: cars & $25.0 \%$ & $68.8 \%$ \\
\hline NR: heavy trucks & $0.0 \%$ & $0.0 \%$ \\
\hline exports: volume index, basis 2005 & $0.0 \%$ & $0.0 \%$ \\
\hline imports: volume index, basis 2005 & $0.0 \%$ & $0.0 \%$ \\
\hline unemployed persons (UNP): total, \% of civilian labor & $0.0 \%$ & $0.0 \%$ \\
\hline employed persons (EMPL): residence concept, total & $0.0 \%$ & $0.0 \%$ \\
\hline EMPL: work-place concept, total & $0.0 \%$ & $0.0 \%$ \\
\hline working days: total & $96.9 \%$ & $84.4 \%$ \\
\hline vacancies: total & $100.0 \%$ & $100.0 \%$ \\
\hline wages and salaries (WS): total economy, hourly basis & $0.0 \%$ & $0.0 \%$ \\
\hline WS: total economy, per employed person & $0.0 \%$ & $0.0 \%$ \\
\hline Euro-Coin real time estimates & $0.0 \%$ & $0.0 \%$ \\
\hline \multicolumn{3}{|l|}{ Prices } \\
\hline consumer price index & $0.0 \%$ & $0.0 \%$ \\
\hline consumer price index (excl. energy) & $0.0 \%$ & $31.3 \%$ \\
\hline producer price index & $0.0 \%$ & $15.6 \%$ \\
\hline wholesale trade price index, $1975=100$ & $0.0 \%$ & $0.0 \%$ \\
\hline export price index & $0.0 \%$ & $0.0 \%$ \\
\hline import price index & $0.0 \%$ & $3.1 \%$ \\
\hline HWWA index of world market prices: eurozone, energy & $0.0 \%$ & $0.0 \%$ \\
\hline HWWA index of world market prices: eurozone, excl. energy & $25.0 \%$ & $0.0 \%$ \\
\hline oil prices, euro per barrel & $0.0 \%$ & $0.0 \%$ \\
\hline UK average brent oil price & $0.0 \%$ & $25.0 \%$ \\
\hline Zdon gold price, per US $\$$ & $6.3 \%$ & $6.3 \%$ \\
\hline \multicolumn{3}{|l|}{ Surveys } \\
\hline ZEW: economic sentiment indicator & $0.0 \%$ & $0.0 \%$ \\
\hline ZEW: present economic situation & $31.3 \%$ & $0.0 \%$ \\
\hline ifo business climate industry and trade & $0.0 \%$ & $0.0 \%$ \\
\hline ifo: assessm. of business situation industry and trade & $0.0 \%$ & $0.0 \%$ \\
\hline ifo: business expectations industry and trade & $0.0 \%$ & $0.0 \%$ \\
\hline ifo: business climate manufacturing & $0.0 \%$ & $0.0 \%$ \\
\hline ifo: assessment of business situation manufacturing & $0.0 \%$ & $0.0 \%$ \\
\hline ifo: business expectations manufacturing & $0.0 \%$ & $0.0 \%$ \\
\hline ifo: inventory of finished goods manufacturing & $0.0 \%$ & $0.0 \%$ \\
\hline ifo: orders on hand manufacturing & $0.0 \%$ & $0.0 \%$ \\
\hline ifo: foreign orders on hand manufacturing & $0.0 \%$ & $0.0 \%$ \\
\hline ifo: export expectations next 3 months manufacturing & $0.0 \%$ & $0.0 \%$ \\
\hline ifo: business climate intermediate goods & $0.0 \%$ & $0.0 \%$ \\
\hline ifo: assessm. of business sit. intermediate goods & $0.0 \%$ & $0.0 \%$ \\
\hline \multirow[t]{2}{*}{ ifo: production expectations intermediate goods } & $0.0 \%$ & $0.0 \%$ \\
\hline & ed on $n \epsilon$ & t page... \\
\hline
\end{tabular}


Table 4: List of indicators and cumulative frequency for BadenWuerttemberg - continued

\begin{tabular}{|c|c|c|}
\hline Indicator & $\mathbf{h}=\mathbf{1}$ & $\mathbf{h}=\mathbf{2}$ \\
\hline ifo: business climate consumer goods & $0.0 \%$ & $0.0 \%$ \\
\hline ifo: assessment of business situation consumer goods & $0.0 \%$ & $0.0 \%$ \\
\hline ifo: business expectations consumer goods & $0.0 \%$ & $0.0 \%$ \\
\hline ifo: business climate capital goods & $0.0 \%$ & $0.0 \%$ \\
\hline ifo: assessment of business situation capital goods & $0.0 \%$ & $0.0 \%$ \\
\hline ifo: production expectations capital goods & $0.0 \%$ & $0.0 \%$ \\
\hline ifo: business climate consumer durables & $6.3 \%$ & $0.0 \%$ \\
\hline ifo: assessment of business situation consumer durables & $0.0 \%$ & $0.0 \%$ \\
\hline ifo: production expectations consumer durables & $90.6 \%$ & $100.0 \%$ \\
\hline ifo: business climate consumer non-durables & $0.0 \%$ & $6.3 \%$ \\
\hline ifo: assessm. of business sit. consumer non-durables & $0.0 \%$ & $0.0 \%$ \\
\hline ifo: production expectations consumer non-durables & $0.0 \%$ & $0.0 \%$ \\
\hline ifo: business climate construction & $0.0 \%$ & $0.0 \%$ \\
\hline ifo: assessment of business situation construction & $0.0 \%$ & $0.0 \%$ \\
\hline ifo: business expectations construction & $0.0 \%$ & $0.0 \%$ \\
\hline ifo: construction unfavourable weather & $0.0 \%$ & $0.0 \%$ \\
\hline ifo: orders on hand construction & $0.0 \%$ & $0.0 \%$ \\
\hline ifo: business climate wholesale trade & $0.0 \%$ & $0.0 \%$ \\
\hline ifo: assessment of business situation wholesale trade & $0.0 \%$ & $0.0 \%$ \\
\hline ifo: business expectations wholesale trade & $0.0 \%$ & $0.0 \%$ \\
\hline ifo: assessment of inventories wholesale trade & $0.0 \%$ & $0.0 \%$ \\
\hline ifo: expect. with regard to order activ. next 3 months WT & $0.0 \%$ & $0.0 \%$ \\
\hline ifo: business climate retail sales & $0.0 \%$ & $0.0 \%$ \\
\hline ifo: assessment of inventories retail sales & $0.0 \%$ & $0.0 \%$ \\
\hline ifo: business expectations retail sales & $0.0 \%$ & $0.0 \%$ \\
\hline ifo: expect. with regard to order activ. next 3 months RS & $0.0 \%$ & $0.0 \%$ \\
\hline EU consumer survey (EUCS): unemploym. expect. next 12 months & $0.0 \%$ & $0.0 \%$ \\
\hline EUCS: statement on financial situation & $0.0 \%$ & $0.0 \%$ \\
\hline EUCS: consumer confidence indicator & $0.0 \%$ & $0.0 \%$ \\
\hline EUCS: economic sentiment indicator & $0.0 \%$ & $0.0 \%$ \\
\hline EU business survey (EUBS): product. trends recent month, ind. & $0.0 \%$ & $0.0 \%$ \\
\hline EUBS: assessment of order-book levels, industry & $0.0 \%$ & $0.0 \%$ \\
\hline EUBS: assessment of export oder-books level, industry & $0.0 \%$ & $0.0 \%$ \\
\hline EUBS: assessment of stocks of finished products, industry & $0.0 \%$ & $0.0 \%$ \\
\hline EUBS: production expectations for the month ahead, industry & $0.0 \%$ & $0.0 \%$ \\
\hline EUBS: selling price expectations for the month ahead, industry & $62.5 \%$ & $59.4 \%$ \\
\hline EUBS: employment expectations for the month ahead, industry & $0.0 \%$ & $0.0 \%$ \\
\hline EUBS: industrial confidence indicator & $0.0 \%$ & $0.0 \%$ \\
\hline EUBS: service sector confidence indicator & $6.3 \%$ & $6.3 \%$ \\
\hline EUBS: retail trade confidence indicator & $68.8 \%$ & $0.0 \%$ \\
\hline EUBS: construction confidence indicator & $0.0 \%$ & $0.0 \%$ \\
\hline \multicolumn{3}{|l|}{ International } \\
\hline Bulgarian business indicator survey, whole economy & $3.1 \%$ & $0.0 \%$ \\
\hline Bulgarian business indicator survey, manufacturing & $0.0 \%$ & $0.0 \%$ \\
\hline EUCS: economic sentiment indicator, France & $0.0 \%$ & $0.0 \%$ \\
\hline EUCS: economic sentiment indicator, Spain & $0.0 \%$ & $0.0 \%$ \\
\hline EUCS: economic sentiment indicator, Poland & $0.0 \%$ & $0.0 \%$ \\
\hline EUCS: economic sentiment indicator, Czech Republic & $0.0 \%$ & $0.0 \%$ \\
\hline EUCS: economic sentiment indicator, Italy & $0.0 \%$ & $0.0 \%$ \\
\hline EUCS: economic sentiment indicator, United Kingdom & $0.0 \%$ & $0.0 \%$ \\
\hline University of Michigan consumer sentiment & $0.0 \%$ & $0.0 \%$ \\
\hline IP: United States, total & $0.0 \%$ & $0.0 \%$ \\
\hline OECD Composite Leading Indicator (CLI): OECD, ampl. adj. & $0.0 \%$ & $0.0 \%$ \\
\hline
\end{tabular}


Table 4: List of indicators and cumulative frequency for BadenWuerttemberg - continued

\begin{tabular}{|c|c|c|}
\hline Indicator & $\mathbf{h}=\mathbf{1}$ & $\mathrm{h}=2$ \\
\hline CLI: OECD, trend restored & $0.0 \%$ & $0.0 \%$ \\
\hline CLI: OECD, normalised & $6.3 \%$ & $0.0 \%$ \\
\hline CLI: Asia, amplitude adjusted & $0.0 \%$ & $9.4 \%$ \\
\hline CLI: Asia, trend restored & $0.0 \%$ & $0.0 \%$ \\
\hline CLI: Asia, normalised & $0.0 \%$ & $3.1 \%$ \\
\hline CLI: China, amplitude adjusted & $31.3 \%$ & $0.0 \%$ \\
\hline CLI: China, trend restored & $0.0 \%$ & $0.0 \%$ \\
\hline CLI: China, normalised & $62.5 \%$ & $59.4 \%$ \\
\hline CLI: Euro Area, amplitude adjusted & $31.3 \%$ & $0.0 \%$ \\
\hline CLI: Euro Area, trend restored & $0.0 \%$ & $0.0 \%$ \\
\hline CLI: Euro Area, normalised & $0.0 \%$ & $50.0 \%$ \\
\hline CLI: United States, amplitude adjusted & $0.0 \%$ & $0.0 \%$ \\
\hline CLI: United States, trend restored & $0.0 \%$ & $0.0 \%$ \\
\hline CLI: United States, normalised & $0.0 \%$ & $0.0 \%$ \\
\hline \multicolumn{3}{|l|}{ Regional } \\
\hline ifo business climate manufacturing, Baden-Wuerttemberg & $0.0 \%$ & $0.0 \%$ \\
\hline ifo BW: assessment of business situation manufacturing & $0.0 \%$ & $0.0 \%$ \\
\hline ifo BW: business expectations manufacturing & $0.0 \%$ & $0.0 \%$ \\
\hline ifo BW: business climate construction & $0.0 \%$ & $0.0 \%$ \\
\hline ifo BW: assessment of business situation construction & $0.0 \%$ & $0.0 \%$ \\
\hline ifo BW: business expectations construction & $0.0 \%$ & $0.0 \%$ \\
\hline ifo BW: employment expectations construction & $0.0 \%$ & $0.0 \%$ \\
\hline ifo BW: business climate wholesale trade & $0.0 \%$ & $0.0 \%$ \\
\hline ifo BW: assessment of business situation wholesale trade & $0.0 \%$ & $0.0 \%$ \\
\hline ifo BW: business expectations wholesale trade & $12.5 \%$ & $3.1 \%$ \\
\hline ifo BW: employment expectations wholesale trade & $0.0 \%$ & $0.0 \%$ \\
\hline ifo BW: business climate retail sales & $0.0 \%$ & $0.0 \%$ \\
\hline ifo BW: assessment of business situation retail sales & $0.0 \%$ & $0.0 \%$ \\
\hline ifo BW: business expectations retail sales & $71.9 \%$ & $59.4 \%$ \\
\hline ifo BW: employment expectations retail sales & $0.0 \%$ & $0.0 \%$ \\
\hline industrial production (IP): total (incl. construction), BW & $3.1 \%$ & $6.3 \%$ \\
\hline turnover (TO): construction total, BW & $15.6 \%$ & $0.0 \%$ \\
\hline TO: housing construction, BW & $0.0 \%$ & $6.3 \%$ \\
\hline TO: commercial construction, BW & $25.0 \%$ & $0.0 \%$ \\
\hline TO: public construction, BW & $12.5 \%$ & $21.9 \%$ \\
\hline new orders (NO): manufacturing domestic, BW & $62.5 \%$ & $6.3 \%$ \\
\hline NO: manufacturing foreign, BW & $3.1 \%$ & $62.5 \%$ \\
\hline NO: construction total, BW & $15.6 \%$ & $3.1 \%$ \\
\hline NO: housing construction, BW & $0.0 \%$ & $6.3 \%$ \\
\hline NO: commercial construction, BW & $21.9 \%$ & $15.6 \%$ \\
\hline NO: public construction, BW & $81.3 \%$ & $31.3 \%$ \\
\hline working hours $(\mathrm{WH})$ : construction total, BW & $0.0 \%$ & $0.0 \%$ \\
\hline WH: housing construction, BW & $0.0 \%$ & $0.0 \%$ \\
\hline WH: commercial construction, BW & $0.0 \%$ & $59.4 \%$ \\
\hline WH: public construction, BW & $53.1 \%$ & $0.0 \%$ \\
\hline number of firms, construction total, BW & $0.0 \%$ & $0.0 \%$ \\
\hline number of employed persons, construction total, BW & $0.0 \%$ & $0.0 \%$ \\
\hline compensations, construction total, BW & $0.0 \%$ & $0.0 \%$ \\
\hline consumer price index, BW & $0.0 \%$ & $0.0 \%$ \\
\hline capacity utilization, construction total, BW & $0.0 \%$ & $0.0 \%$ \\
\hline business cycle indicator BW & $0.0 \%$ & $46.9 \%$ \\
\hline
\end{tabular}

Note: The table presents the relative frequencies of all indicators in our sample for the different forecasting horizons. A value of $100 \%$ is reached if an indicator gets chosen by the algorithm 32 times, thus, for the length of our forecasting period. An indicator is assigned with $0 \%$ if this indicator is not chosen over the forecasting period at all. 
Table 5: List of indicators and cumulative frequency for Eastern Germany

\begin{tabular}{|c|c|c|}
\hline Indicator & $\mathbf{h}=\mathbf{1}$ & $\mathbf{h}=\mathbf{2}$ \\
\hline \multicolumn{3}{|l|}{ Target variable } \\
\hline gross domestic product (GDP): Eastern Germany & $62.5 \%$ & $0.0 \%$ \\
\hline \multicolumn{3}{|l|}{ Macroeconomic variables } \\
\hline industrial production (IP): total (incl. construction) & $0.0 \%$ & $0.0 \%$ \\
\hline IP manufacturing: total & $0.0 \%$ & $0.0 \%$ \\
\hline IP manufacturing: intermediate goods & $0.0 \%$ & $0.0 \%$ \\
\hline IP manufacturing: consumer goods & $0.0 \%$ & $12.5 \%$ \\
\hline IP manufacturing: capital goods & $0.0 \%$ & $0.0 \%$ \\
\hline IP manufacturing: consumer durables & $25.0 \%$ & $0.0 \%$ \\
\hline IP manufacturing: consumer non-durables & $0.0 \%$ & $3.1 \%$ \\
\hline IP manufacturing: mining and quarrying & $0.0 \%$ & $0.0 \%$ \\
\hline IP manufacturing: chemicals & $0.0 \%$ & $0.0 \%$ \\
\hline IP manufacturing: basic metals & $0.0 \%$ & $0.0 \%$ \\
\hline IP manufacturing: mechanical engineering & $0.0 \%$ & $15.6 \%$ \\
\hline IP manufacturing: motor vehicles, trailers etc. & $0.0 \%$ & $0.0 \%$ \\
\hline IP construction: total & $65.6 \%$ & $25.0 \%$ \\
\hline IP energy supply: total & $0.0 \%$ & $0.0 \%$ \\
\hline turnover (TO): manufacturing total, domestic & $0.0 \%$ & $0.0 \%$ \\
\hline TO: manufacturing total, foreign & $0.0 \%$ & $0.0 \%$ \\
\hline TO: intermediate goods, domestic & $28.1 \%$ & $0.0 \%$ \\
\hline TO: intermediate goods, foreign & $0.0 \%$ & $0.0 \%$ \\
\hline TO: consumer goods, domestic & $0.0 \%$ & $0.0 \%$ \\
\hline TO: consumer goods, foreign & $0.0 \%$ & $0.0 \%$ \\
\hline TO: capital goods, domestic & $0.0 \%$ & $0.0 \%$ \\
\hline TO: capital goods, foreign & $0.0 \%$ & $0.0 \%$ \\
\hline TO: consumer durables, domestic & $6.3 \%$ & $0.0 \%$ \\
\hline TO: consumer durables, foreign & $0.0 \%$ & $0.0 \%$ \\
\hline TO: consumer non-durables, domestic & $0.0 \%$ & $50.0 \%$ \\
\hline TO: consumer non-durables, foreign & $0.0 \%$ & $0.0 \%$ \\
\hline TO: mining and quarrying, domestic & $0.0 \%$ & $0.0 \%$ \\
\hline TO: mining and quarrying, foreign & $0.0 \%$ & $0.0 \%$ \\
\hline TO: energy, gas etc. supply, domestic & $0.0 \%$ & $9.4 \%$ \\
\hline TO: energy, gas etc. supply, foreign & $0.0 \%$ & $0.0 \%$ \\
\hline TO: chemicals, domestic & $0.0 \%$ & $21.9 \%$ \\
\hline TO: chemicals, foreign & $0.0 \%$ & $0.0 \%$ \\
\hline TO: mechanical engineering, domestic & $0.0 \%$ & $0.0 \%$ \\
\hline TO: mechanical engineering, foreign & $0.0 \%$ & $0.0 \%$ \\
\hline TO: motor vehicles, trailers etc., domestic & $3.1 \%$ & $0.0 \%$ \\
\hline TO: motor vehicles, trailers etc., foreign & $3.1 \%$ & $0.0 \%$ \\
\hline TO: comp., electr. and opt. prod., domestic & $0.0 \%$ & $0.0 \%$ \\
\hline TO: comp., electr. and opt. prod., foreign & $0.0 \%$ & $0.0 \%$ \\
\hline new orders (NO): manufacturing total & $0.0 \%$ & $0.0 \%$ \\
\hline NO: manufacturing total, domestic & $3.1 \%$ & $0.0 \%$ \\
\hline NO: manufacturing total, foreign & $0.0 \%$ & $0.0 \%$ \\
\hline NO: intermediate goods & $0.0 \%$ & $0.0 \%$ \\
\hline NO: intermediate goods, domestic & $9.4 \%$ & $0.0 \%$ \\
\hline NO: intermediate goods, foreign & $0.0 \%$ & $0.0 \%$ \\
\hline NO: consumer goods & $59.4 \%$ & $18.8 \%$ \\
\hline \multirow[t]{2}{*}{ NO: consumer goods, domestic } & $6.3 \%$ & $0.0 \%$ \\
\hline & ed on ne & page... \\
\hline
\end{tabular}


Table 5: List of indicators and cumulative frequency for Eastern Germany - continued

\begin{tabular}{|c|c|c|}
\hline Indicator & $\mathbf{h}=\mathbf{1}$ & $\mathbf{h}=\mathbf{2}$ \\
\hline NO: consumer goods, foreign & $0.0 \%$ & $0.0 \%$ \\
\hline NO: capital goods & $0.0 \%$ & $0.0 \%$ \\
\hline NO: capital goods, domestic & $0.0 \%$ & $0.0 \%$ \\
\hline NO: capital goods, foreign & $0.0 \%$ & $0.0 \%$ \\
\hline NO: chemicals, domestic & $0.0 \%$ & $0.0 \%$ \\
\hline NO: chemicals, foreign & $0.0 \%$ & $0.0 \%$ \\
\hline NO: mechanical engineering, domestic & $0.0 \%$ & $0.0 \%$ \\
\hline NO: mechanical engineering, foreign & $0.0 \%$ & $0.0 \%$ \\
\hline NO: motor vehicles, trailers etc., domestic & $37.5 \%$ & $40.6 \%$ \\
\hline NO: motor vehicles, trailers etc., foreign & $0.0 \%$ & $0.0 \%$ \\
\hline NO: comp., electr. and opt. prod., domestic & $0.0 \%$ & $0.0 \%$ \\
\hline NO: comp., electr. and opt. prod., foreign & $0.0 \%$ & $0.0 \%$ \\
\hline wholesale trade (WT): total employment & $0.0 \%$ & $0.0 \%$ \\
\hline retail sales (RS): turnover, total (excl. cars) & $43.8 \%$ & $6.3 \%$ \\
\hline new registrations (NR): all vehicles & $0.0 \%$ & $50.0 \%$ \\
\hline NR: cars & $0.0 \%$ & $18.8 \%$ \\
\hline NR: heavy trucks & $0.0 \%$ & $21.9 \%$ \\
\hline exports: volume index, basis 2005 & $0.0 \%$ & $0.0 \%$ \\
\hline imports: volume index, basis 2005 & $0.0 \%$ & $0.0 \%$ \\
\hline unemployed persons (UNP): total, \% of civilian labor & $0.0 \%$ & $0.0 \%$ \\
\hline employed persons (EMPL): residence concept, total & $0.0 \%$ & $0.0 \%$ \\
\hline EMPL: work-place concept, total & $0.0 \%$ & $0.0 \%$ \\
\hline working days: total & $0.0 \%$ & $3.1 \%$ \\
\hline vacancies: total & $96.9 \%$ & $93.8 \%$ \\
\hline wages and salaries (WS): total economy, hourly basis & $0.0 \%$ & $0.0 \%$ \\
\hline WS: total economy, per employed person & $0.0 \%$ & $0.0 \%$ \\
\hline Euro-Coin real time estimates & $0.0 \%$ & $0.0 \%$ \\
\hline \multicolumn{3}{|l|}{ Prices } \\
\hline consumer price index & $0.0 \%$ & $0.0 \%$ \\
\hline consumer price index (excl. energy) & $0.0 \%$ & $0.0 \%$ \\
\hline producer price index & $3.1 \%$ & $0.0 \%$ \\
\hline wholesale trade price index, $1975=100$ & $0.0 \%$ & $18.8 \%$ \\
\hline export price index & $0.0 \%$ & $6.3 \%$ \\
\hline import price index & $0.0 \%$ & $0.0 \%$ \\
\hline HWWA index of world market prices: eurozone, energy & $0.0 \%$ & $0.0 \%$ \\
\hline HWWA index of world market prices: eurozone, excl. energy & $0.0 \%$ & $0.0 \%$ \\
\hline oil prices, euro per barrel & $0.0 \%$ & $0.0 \%$ \\
\hline UK average brent oil price & $0.0 \%$ & $15.6 \%$ \\
\hline London gold price, per US $\$$ & $0.0 \%$ & $18.8 \%$ \\
\hline \multicolumn{3}{|l|}{ Surveys } \\
\hline ZEW: economic sentiment indicator & $0.0 \%$ & $0.0 \%$ \\
\hline ZEW: present economic situation & $0.0 \%$ & $0.0 \%$ \\
\hline ifo business climate industry and trade & $0.0 \%$ & $0.0 \%$ \\
\hline ifo: assessm. of business situation industry and trade & $0.0 \%$ & $0.0 \%$ \\
\hline ifo: business expectations industry and trade & $0.0 \%$ & $0.0 \%$ \\
\hline ifo: business climate manufacturing & $0.0 \%$ & $0.0 \%$ \\
\hline ifo: assessment of business situation manufacturing & $0.0 \%$ & $0.0 \%$ \\
\hline ifo: business expectations manufacturing & $0.0 \%$ & $0.0 \%$ \\
\hline ifo: inventory of finished goods manufacturing & $0.0 \%$ & $0.0 \%$ \\
\hline ifo: orders on hand manufacturing & $0.0 \%$ & $0.0 \%$ \\
\hline ifo: foreign orders on hand manufacturing & $0.0 \%$ & $0.0 \%$ \\
\hline ifo: export expectations next 3 months manufacturing & $0.0 \%$ & $0.0 \%$ \\
\hline \multirow[t]{2}{*}{ ifo: business climate intermediate goods } & $0.0 \%$ & $0.0 \%$ \\
\hline & on $n \epsilon$ & page... \\
\hline
\end{tabular}


Table 5: List of indicators and cumulative frequency for Eastern Germany - continued

\begin{tabular}{|c|c|c|}
\hline Indicator & $\mathbf{h}=\mathbf{1}$ & $\mathbf{h}=\mathbf{2}$ \\
\hline ifo: assessm. of business sit. intermediate goods & $0.0 \%$ & $3.1 \%$ \\
\hline ifo: production expectations intermediate goods & $15.6 \%$ & $0.0 \%$ \\
\hline ifo: business climate consumer goods & $0.0 \%$ & $0.0 \%$ \\
\hline ifo: assessment of business situation consumer goods & $0.0 \%$ & $0.0 \%$ \\
\hline ifo: business expectations consumer goods & $0.0 \%$ & $0.0 \%$ \\
\hline ifo: business climate capital goods & $0.0 \%$ & $0.0 \%$ \\
\hline ifo: assessment of business situation capital goods & $0.0 \%$ & $0.0 \%$ \\
\hline ifo: production expectations capital goods & $0.0 \%$ & $0.0 \%$ \\
\hline ifo: business climate consumer durables & $0.0 \%$ & $0.0 \%$ \\
\hline ifo: assessment of business situation consumer durables & $0.0 \%$ & $0.0 \%$ \\
\hline ifo: production expectations consumer durables & $50.0 \%$ & $53.1 \%$ \\
\hline ifo: business climate consumer non-durables & $0.0 \%$ & $0.0 \%$ \\
\hline ifo: assessm. of business sit. consumer non-durables & $0.0 \%$ & $0.0 \%$ \\
\hline ifo: production expectations consumer non-durables & $9.4 \%$ & $0.0 \%$ \\
\hline ifo: business climate construction & $0.0 \%$ & $0.0 \%$ \\
\hline ifo: assessment of business situation construction & $0.0 \%$ & $3.1 \%$ \\
\hline ifo: business expectations construction & $0.0 \%$ & $0.0 \%$ \\
\hline ifo: construction unfavourable weather & $0.0 \%$ & $25.0 \%$ \\
\hline ifo: orders on hand construction & $0.0 \%$ & $0.0 \%$ \\
\hline ifo: business climate wholesale trade & $0.0 \%$ & $0.0 \%$ \\
\hline ifo: assessment of business situation wholesale trade & $0.0 \%$ & $0.0 \%$ \\
\hline ifo: business expectations wholesale trade & $0.0 \%$ & $0.0 \%$ \\
\hline ifo: assessment of inventories wholesale trade & $0.0 \%$ & $0.0 \%$ \\
\hline ifo: expect. with regard to order activ. next 3 months WT & $0.0 \%$ & $0.0 \%$ \\
\hline ifo: business climate retail sales & $0.0 \%$ & $0.0 \%$ \\
\hline ifo: assessment of inventories retail sales & $0.0 \%$ & $0.0 \%$ \\
\hline ifo: business expectations retail sales & $0.0 \%$ & $0.0 \%$ \\
\hline ifo: expect. with regard to order activ. next 3 months RS & $0.0 \%$ & $0.0 \%$ \\
\hline EU consumer survey (EUCS): unemploym. expect. next 12 months & $0.0 \%$ & $0.0 \%$ \\
\hline EUCS: statement on financial situation & $0.0 \%$ & $0.0 \%$ \\
\hline EUCS: consumer confidence indicator & $0.0 \%$ & $0.0 \%$ \\
\hline EUCS: economic sentiment indicator & $0.0 \%$ & $0.0 \%$ \\
\hline EU business survey (EUBS): product. trends recent month, ind. & $0.0 \%$ & $0.0 \%$ \\
\hline EUBS: assessment of order-book levels, industry & $0.0 \%$ & $0.0 \%$ \\
\hline EUBS: assessment of export oder-books level, industry & $0.0 \%$ & $15.6 \%$ \\
\hline EUBS: assessment of stocks of finished products, industry & $0.0 \%$ & $0.0 \%$ \\
\hline EUBS: production expectations for the month ahead, industry & $0.0 \%$ & $0.0 \%$ \\
\hline EUBS: selling price expectations for the month ahead, industry & $0.0 \%$ & $28.1 \%$ \\
\hline EUBS: employment expectations for the month ahead, industry & $0.0 \%$ & $0.0 \%$ \\
\hline EUBS: industrial confidence indicator & $0.0 \%$ & $0.0 \%$ \\
\hline EUBS: service sector confidence indicator & $3.1 \%$ & $6.3 \%$ \\
\hline EUBS: retail trade confidence indicator & $0.0 \%$ & $0.0 \%$ \\
\hline EUBS: construction confidence indicator & $0.0 \%$ & $0.0 \%$ \\
\hline \multicolumn{3}{|l|}{ International } \\
\hline Bulgarian business indicator survey, whole economy & $0.0 \%$ & $0.0 \%$ \\
\hline Bulgarian business indicator survey, manufacturing & $0.0 \%$ & $9.4 \%$ \\
\hline EUCS: economic sentiment indicator, France & $0.0 \%$ & $0.0 \%$ \\
\hline EUCS: economic sentiment indicator, Spain & $0.0 \%$ & $0.0 \%$ \\
\hline EUCS: economic sentiment indicator, Poland & $0.0 \%$ & $0.0 \%$ \\
\hline EUCS: economic sentiment indicator, Czech Republic & $0.0 \%$ & $0.0 \%$ \\
\hline EUCS: economic sentiment indicator, Italy & $0.0 \%$ & $0.0 \%$ \\
\hline EUCS: economic sentiment indicator, United Kingdom & $0.0 \%$ & $0.0 \%$ \\
\hline University of Michigan consumer sentiment & $0.0 \%$ & $0.0 \%$ \\
\hline \multicolumn{3}{|c|}{ d on next page... } \\
\hline
\end{tabular}


Table 5: List of indicators and cumulative frequency for Eastern Germany - continued

\begin{tabular}{|c|c|c|}
\hline Indicator & $h=1$ & $\mathbf{h}=\mathbf{2}$ \\
\hline IP: United States, total & $0.0 \%$ & $0.0 \%$ \\
\hline OECD Composite Leading Indicator (CLI): OECD, ampl. adj. & $3.1 \%$ & $0.0 \%$ \\
\hline CLI: OECD, trend restored & $0.0 \%$ & $0.0 \%$ \\
\hline CLI: OECD, normalised & $71.9 \%$ & $43.8 \%$ \\
\hline CLI: Asia, amplitude adjusted & $40.6 \%$ & $3.1 \%$ \\
\hline CLI: Asia, trend restored & $0.0 \%$ & $0.0 \%$ \\
\hline CLI: Asia, normalised & $0.0 \%$ & $0.0 \%$ \\
\hline CLI: China, amplitude adjusted & $0.0 \%$ & $0.0 \%$ \\
\hline CLI: China, trend restored & $0.0 \%$ & $0.0 \%$ \\
\hline CLI: China, normalised & $62.5 \%$ & $59.4 \%$ \\
\hline CLI: Euro Area, amplitude adjusted & $0.0 \%$ & $0.0 \%$ \\
\hline CLI: Euro Area, trend restored & $0.0 \%$ & $6.3 \%$ \\
\hline CLI: Euro Area, normalised & $0.0 \%$ & $6.3 \%$ \\
\hline CLI: United States, amplitude adjusted & $21.9 \%$ & $0.0 \%$ \\
\hline CLI: United States, trend restored & $0.0 \%$ & $18.8 \%$ \\
\hline CLI: United States, normalised & $100.0 \%$ & $50.0 \%$ \\
\hline \multicolumn{3}{|l|}{ Regional } \\
\hline ifo EG: business climate manufacturing & $0.0 \%$ & $0.0 \%$ \\
\hline ifo EG: assessment of business situation manufacturing & $0.0 \%$ & $0.0 \%$ \\
\hline ifo EG: business expectations manufacturing & $9.4 \%$ & $0.0 \%$ \\
\hline ifo EG: business climate construction & $0.0 \%$ & $0.0 \%$ \\
\hline ifo EG: assessment of business situation construction & $0.0 \%$ & $0.0 \%$ \\
\hline ifo EG: business expectations construction & $0.0 \%$ & $0.0 \%$ \\
\hline ifo EG: employment expectations construction & $0.0 \%$ & $0.0 \%$ \\
\hline ifo EG: business climate wholesale trade & $0.0 \%$ & $0.0 \%$ \\
\hline ifo EG: assessment of business situation wholesale trade & $0.0 \%$ & $0.0 \%$ \\
\hline ifo EG: business expectations wholesale trade & $34.4 \%$ & $21.9 \%$ \\
\hline ifo EG: employment expectations wholesale trade & $0.0 \%$ & $0.0 \%$ \\
\hline ifo EG: business climate retail sales & $0.0 \%$ & $0.0 \%$ \\
\hline ifo EG: assessment of business situation retail sales & $0.0 \%$ & $0.0 \%$ \\
\hline ifo EG: business expectations retail sales & $0.0 \%$ & $0.0 \%$ \\
\hline ifo EG: employment expectations retail sales & $0.0 \%$ & $0.0 \%$ \\
\hline turnover (TO): manufacturing, EG & $0.0 \%$ & $0.0 \%$ \\
\hline TO: construction total, EG & $0.0 \%$ & $0.0 \%$ \\
\hline TO: housing construction, EG & $0.0 \%$ & $0.0 \%$ \\
\hline TO: commercial construction, EG & $0.0 \%$ & $15.6 \%$ \\
\hline TO: public construction, EG & $0.0 \%$ & $0.0 \%$ \\
\hline new orders (NO): construction total, EG & $0.0 \%$ & $0.0 \%$ \\
\hline NO: housing construction, EG & $3.1 \%$ & $0.0 \%$ \\
\hline NO: commercial construction, EG & $0.0 \%$ & $34.4 \%$ \\
\hline NO: public construction, EG & $0.0 \%$ & $0.0 \%$ \\
\hline working hours (WH): construction total, EG & $0.0 \%$ & $0.0 \%$ \\
\hline WH: housing construction, EG & $0.0 \%$ & $0.0 \%$ \\
\hline WH: commercial construction, EG & $0.0 \%$ & $0.0 \%$ \\
\hline WH: public construction, EG & $0.0 \%$ & $0.0 \%$ \\
\hline number of firms, construction total, EG & $0.0 \%$ & $0.0 \%$ \\
\hline number of employed persons, construction total, EG & $0.0 \%$ & $0.0 \%$ \\
\hline compensations, construction total, EG & $0.0 \%$ & $0.0 \%$ \\
\hline consumer price index, EG & $0.0 \%$ & $0.0 \%$ \\
\hline capacity utilization, construction total, EG & $0.0 \%$ & $0.0 \%$ \\
\hline IWH business survey: business situation manufacturing, EG & $0.0 \%$ & $0.0 \%$ \\
\hline IWH: business expectations manufacturing, EG & $0.0 \%$ & $0.0 \%$ \\
\hline \multirow[t]{2}{*}{ IWH: business situation construction, EG } & $25.0 \%$ & $25.0 \%$ \\
\hline & ed on nex & page... \\
\hline
\end{tabular}


Table 5: List of indicators and cumulative frequency for Eastern Germany - continued

\begin{tabular}{lrr}
\hline Indicator & $\mathbf{h}=\mathbf{1}$ & $\mathbf{h}=\mathbf{2}$ \\
\hline IWH: business expectations construction, EG & $0.0 \%$ & $0.0 \%$ \\
\hline Note: The table presents the relative frequencies of all indicators in our sample for the \\
different forecasting horizons. A value of 100\% is reached if an indicator gets chosen by \\
the algorithm 32 times, thus, for the length of our forecasting period. An indicator is \\
assigned with $0 \%$ if this indicator is not chosen over the forecasting period at all.
\end{tabular}

